\title{
Lactate in the Tumor Microenvironment: An Essential Molecule in Cancer Progression and Treatment
}

\author{
Ricardo Pérez-Tomás ${ }^{1, *(1)}$ and Isabel Pérez-Guillén ${ }^{2}$ \\ 1 Cancer Cell Biology Research Group, Department of Pathology and Experimental Therapeutics, Faculty of \\ Medicine and Health Sciences, University of Barcelona, C./ Feixa Llarga s/n, L' Hospitalet de Llobregat, \\ 08905 Barcelona, Spain \\ 2 Microbiology Unit, Department of Pathology and Experimental Therapeutics, Faculty of Medicine and \\ Health Sciences, University of Barcelona, C./ Feixa Llarga s/n, L' Hospitalet de Llobregat, 08905 Barcelona, \\ Spain; isaperezguillen@ub.edu \\ * Correspondence: rperez@ub.edu; Tel.: +34-93-4024288
}

Received: 20 September 2020; Accepted: 28 October 2020; Published: 3 November 2020

check for updates

Simple Summary: The role of lactate in cancer described by Otto Warburg in 1927 states that cancer cells uptake high amount of glucose with a marked increase in lactate production, this is known as the "Warburg effect". Since then lactate turn out to be a major signaling molecule in cancer progression. Its release from tumor cells is accompanied by acidification ranging from 6.3 to 6.9 in the tumor microenvironment (TME) which favors processes such as tumor promotion, angiogenesis, metastasis, tumor resistance and more importantly, immunosuppression which has been associated with a poor outcome. The goal of this review is to examine and discuss in deep detail the recent studies that address the role of lactate in all these cancerous processes. Lastly, we explore the efforts to target the lactate production and its transport as a promising approach for cancer therapeutics.

\begin{abstract}
Cancer is a complex disease that includes the reprogramming of metabolic pathways by malignant proliferating cells, including those affecting the tumor microenvironment (TME). The "TME concept" was introduced in recognition of the roles played by factors other than tumor cells in cancer progression. In response to the hypoxic or semi-hypoxic characteristic of the TME, cancer cells generate a large amount of lactate via the metabolism of glucose and glutamine. Export of this newly generated lactate by the tumor cells together with $\mathrm{H}+$ prevents intracellular acidification but acidifies the TME. In recent years, the importance of lactate and acidosis in carcinogenesis has gained increasing attention, including the role of lactate as a tumor-promoting metabolite. Here we review the existing literature on lactate metabolism in tumor cells and the ability of extracellular lactate to direct the metabolic reprogramming of those cells. Studies demonstrating the roles of lactate in biological processes that drive or sustain carcinogenesis (tumor promotion, angiogenesis, metastasis and tumor resistance) and lactate's role as an immunosuppressor that contributes to tumor evasion are also considered. Finally, we consider recent therapeutic efforts using available drugs directed at and interfering with lactate production and transport in cancer treatment.
\end{abstract}

Keywords: lactate; tumor microenvironment (TME), acidosis; LDH; MCTs

\section{Introduction}

In 1922, Archibald V. Hill and Otto Meyerhoff received a Nobel Prize for their work on the energetics of carbohydrate catabolism in skeletal muscle [1]. Hill had quantified the energy released from the conversion of glucose to lactic acid and determined that glucose oxidation occurs during limited oxygen availability. Meyerhoff elucidated most of the glycolytic pathway and demonstrated 
that lactic acid is a byproduct of glycolysis, initiated in the absence of oxygen [2]. (For readers interested in the history of lactate, the 2005 review by Phil et al. [3] is recommended).

Cancer cells have an enormous capacity to regulate their metabolism to promote tumor formation, establishment and survival. In fact, this ability is considered a hallmark of cancer [4]. The increased metabolic rates of several types of neoplasm were first discovered by Otto Warburg in 1927. Warburg showed that neoplastic cells use large amounts of glucose as a primary energy source, even in the presence of oxygen, and thus produce large amounts of lactate, a process referred to as aerobic glycolysis [5]. While less efficient than the full cycle of glycolysis linked to the Krebs cycle and oxidative phosphorylation (oxphos) in terms of ATP production (two ATP per glucose molecule vs. 38 ATP per glucose molecule), aerobic glycolysis generates ATP much faster [6]. In resting normal cells, the glycolytic rate is low and most glucose is converted into carbon dioxide and water. However, in proliferating normal cells, and especially in cancer cells, aerobic glycolysis results in the conversion of as much as $85 \%$ of the incoming glucose to lactate [7] (Figure 1). Thus, in 1972, Efraim Racker referred to the high rate of aerobic glycolysis by cancer cells as the "Warburg effect." It describes the decrease in the oxphos of glucose that supports tumor survival and metastasis [8].

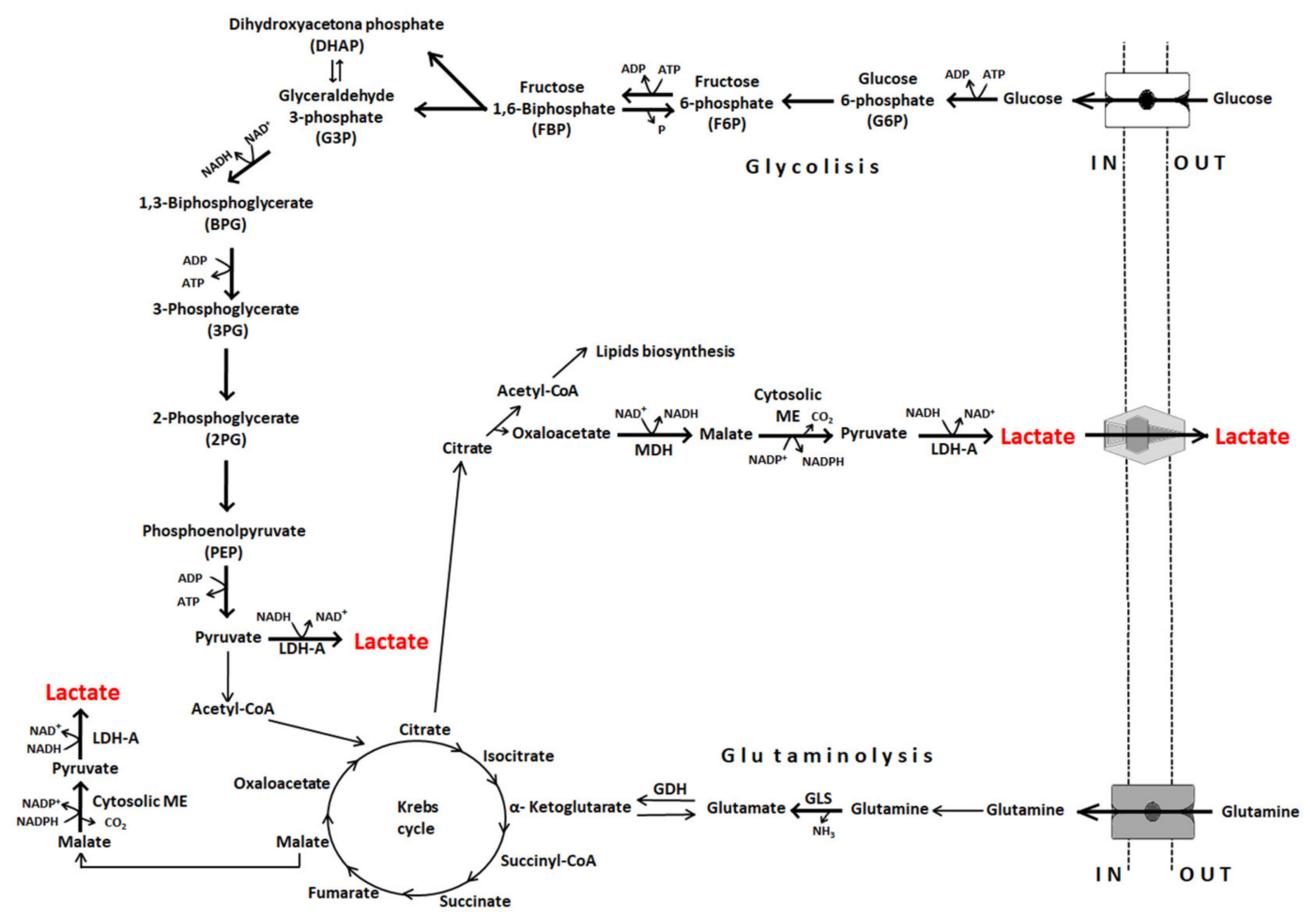

Figure 1. The main biochemical pathways implicated in cancer cell lactate generation. ME, malic enzyme; MDH, malate dehydrogenase; LDH-A, lactate dehydrogenase A; GLS, glutaminase; GDH, glutamate dehydrogenase.

Along with the Warburg effect, glutaminolysis is the most important source of lactate and protons in cancer cells and the cancer environment $[8,9]$. Glutamine serves as a cell nutrient, entering the cells via the glutamine transporter ASCT2 and the neutral amino acid transporter SLC1A5 [10]. In the mitochondria, glutamine is converted to glutamate, which in turn is converted to $\alpha$-ketoglutarate and either fed into the Krebs cycle (Figure 1) or used for the production of glutathione, a major thiol-containing endogenous antioxidant and an essential player in tumor cell survival [11].

Although long considered to be a "metabolic waste product," it is now clear that lactate plays a critical role in fueling the proliferation of tumor cells and in carcinogenic signaling [12], metastasis [13] and tumor resistance [14]. In this review, we discuss the roles of cellular lactate synthesis, transport and exchange in driving and sustaining carcinogenesis, specifically tumor promotion, immune escape 
angiogenesis, metastasis and tumor drug resistance. These same features suggest that the targeting of lactate production and transport offers a novel approach to the treatment of cancer.

\section{The Tumor Microenvironment and the Reversed pH Gradient}

Large amounts of lactic acid and $\mathrm{H}^{+}$produced during aerobic glycolysis and glutaminolysis are released into the extracellular space, thereby entering the tumor microenvironment (TME) [15]. This complex, dynamic cellular compartment is an integral, essential feature of cancer-a major contributor to the aggressiveness of the disease, a determinant of the therapeutic response, but also itself a potential target for therapeutic intervention $[16,17]$. It is a heterogeneous niche harboring the physical and physiological components that empower tumor cells to progress and metastasize $[4,18]$. Among the physical components of the TME are tumor cells, endothelial cells, cancer-associated fibroblasts (CAFs), immune cells, blood vessels, extracellular matrix (ECM), growth factors and cellular metabolites [15]. The physiological components consist of oxygen, $\mathrm{pH}$, nutrients, metabolic products, signaling molecules, reducing/oxidizing species, growth factors and protumorigenic factors.

Lactate is one of the most significant metabolites in the TME. Whereas physiological concentrations of lactate in blood and healthy tissue are in the range of 1.5-3 $\mathrm{mM}$ [19], the release of lactate from tumor cells can result in extracellular concentrations as high as $40 \mathrm{mM}$ [20]. This was demonstrated by Fisher et al. in 2017 [21], who found high levels of lactate in the sera of patients with different types of cancers (breast, gastrointestinal, lung and urogenital cancers; melanoma; sarcoma; etc.). Another important physiological feature of the TME is the hypoxia [22] arising from the imbalanced angiogenesis characteristic of most tumors. Hypoxia induces changes in cellular metabolic pathways, including an even greater dependence on aerobic glycolysis, which together with glutaminolysis increases lactate production.

Furthermore, while under normal physiological conditions, the $\mathrm{pH}$ of blood and tissues is tightly controlled at around $\mathrm{pH} 7.4$; in the TME the local $\mathrm{pH}$ typically ranges from 5.6 to 7.0 [23]. In fact, nearly all tumors show an increase in intracellular $\mathrm{pH}(\mathrm{pHi}=7.3-7.7)$ and a decrease in extracellular $\mathrm{pH}$ $(\mathrm{pHe}=6.3-6.9)$ compared to healthy tissue $(\mathrm{pHi}=7.0, \mathrm{pHe}=7.4)$. This "reversed $\mathrm{pH}$ gradient" [24-26] is a property of all actively growing cells [27], which suggests its evolutionary importance [24]. Numerous processes essential to normal cellular metabolism are highly $\mathrm{pH}$ sensitive in the physiologically relevant range. These include the activities of lactate dehydrogenases (LDHs, discussed in detail below) and the gluconeogenic enzyme phosphofructokinase (PFK) [28,29], both of which require an alkaline $\mathrm{pH}$. An increased $\mathrm{pHi}$ also enhances cancer cell properties such as proliferation [30] and promotes cell survival by limiting apoptosis [31]. Specifically, the glycolytic flux, essential for metabolic reprogramming, is stimulated by an alkaline cytosol, whereas the caspase-induced activation of apoptosis depends on a mild acidification of the cytosol [32].

At the same time, a decreased pHe creates the perfect environment for many of the acquired characteristics of cancers cells, in addition to facilitating tumor immune escape and effective proteolytic degradation of the ECM by invading tumor cells [33,34]. ATP hydrolysis coupled with glycolysis is the main source of the $\mathrm{H}+$ that results in the decreased extracellular $\mathrm{pH}$ [35]. The inefficient removal of $\mathrm{H}+$ and lactic acid from the extracellular space, due to the poorly perfused, dense tumor tissue, acidifies the TME and contributes to the reversed $\mathrm{pH}$ gradient [36]. The development of this tumor phenotype is an early event in tumorigenesis that becomes more prominent with the progression of cancer, as its maintenance reinforces the metabolic adaptation, survival, invasion, immune evasion and drug resistance of tumor cells. In fact, together with genome instability, a reversed $\mathrm{pH}$ gradient can be considered as an underlying cellular requirement in tumorigenesis. The TME is now widely recognized as an integral and essential component of cancer, a major contributor to the aggressiveness and treatment resistance of the disease, but also a potential target for therapeutic intervention [16,17]. 


\section{Lactate Dehydrogenases}

Lactate dehydrogenases (LDHs) are a group of metabolic enzymes that simultaneously catalyze the reversible conversion of pyruvate to lactate and play an important role in cancer metabolism [37]. Of the five LDH isoenzymes described (LDH-1-5), LDH-5, also known as LDHA, and LDH-1, also referred to as LDHB, are of interest in this review.

LDHA preferentially reduces pyruvate to lactate during glycolysis, accompanied by the regeneration of $\mathrm{NADH}$ to $\mathrm{NAD}^{+}$, hence minimizing pyruvate entry into the Krebs cycle in the mitochondria. Thus, LDHA ensures the maintenance of a "fuel" supply in cancer cells in addition to supporting tumor growth and invasion even under hypoxic conditions. Moreover, LDHA activity can be further enhanced by post-translational modifications, such as the phosphorylation of tyrosine-10, which has been shown to contribute to tumor metastasis by altering cell metabolism $[38,39]$. The expression of LDHA is regulated by the oncogene c-Myc and by hypoxia-inducing factor 1 (HIF-1) and microRNA miR-34a [40,41]. Associations of the increased expression of LDHA with a lower event-free survival rate and resistance to chemotherapy have been demonstrated in numerous tumors [42]. Furthermore, high-level LDHA expression serves as a prognostic indicator in patients with different cancers [43].

LDHB supports the conversion of lactate to pyruvate in cells that use lactate as a nutrient for oxidative metabolism or gluconeogenesis [44]. The protons generated by the enzyme promote V-ATPase-dependent lysosomal acidification and autophagy, creating an additional source of energetic and biosynthetic precursors in metabolically restricted microenvironments [45]. The importance of LDHB in the progression of various cancers has been reported [46]. The direct interaction of Aurora-A with LDHB results in phosphorylation of the enzyme (S162). The resulting increases in catalytic activity boost $\mathrm{NAD}^{+}$regeneration, glycolytic flux and the biosynthesis of glycolytic metabolites, all of which facilitate tumor progression [47].

Together, LDHA and LDHB not only ensure the metabolic plasticity of neoplastic cells-which allows them to adapt to hostile environmental or cellular conditions, such as the increased production of reactive oxygen species-but also regulate cell death (apoptosis and autophagy) [48]. Thus, the role of these enzymes in tumor biology is more complex than was initially expected, but this may also create an opportunity to target them in the treatment of cancer.

\section{Lactate Transport}

The metabolic processes of cancer cells result in the accumulation of lactate in the cytosol, which together with the accumulated $\mathrm{H}+$ must be released into the extracellular space: (i) to prevent intracellular acidification and (ii) to support high rates of glycolysis, as high concentrations of lactate in the cytosol reduce the glycolytic rate by inhibiting the rate-limiting enzyme PFK-1 [49,50]. The release of lactate and $\mathrm{H}+$ into the TME [15] is mediated by monocarboxylate transporters (MCTs) and Na-driven proton extrusion, respectively [51,52]. The reliance of lactate removal on MCTs is necessitated by the fact that lactic acid is hydrophilic and a weak acid and thus unable to freely diffuse across the cell membrane. The pKa of the lactate/lactic acid pair is 3.8 at physiological $\mathrm{pH}$, with lactic acid immediately dissociating into lactate (base form) and hydrogen $(\mathrm{H}+)$. Nonetheless, several studies conducted in the 1990s clearly showed that lactate is not responsible for extracellular acidosis; rather, ATP hydrolysis coupled with glycolysis is the main source of $\mathrm{H}+$ production that leads to a decrease in the extracellular $\mathrm{pH}$ [35].

MCTs belong to the solute carrier transporter family (SLC), composed of 52 families of membrane transport proteins. One of these families, SLC16, encodes $14 \mathrm{MCT}$ isoforms with significant roles in the absorption, tissue distribution and clearance of both endogenous and exogenous compounds [53]. However, only four isoforms (MCT1-4) are lactate transporters, although they can also carry other monocarboxylates, such as pyruvate and ketone bodies [54]. MCT1 facilitates both lactate and pyruvate upload, whilst MCT4 exports lactate and $\mathrm{H}+$, and thereby contributes to the reversed $\mathrm{pH}$ gradient [55]. The direction of lactic acid exchange depends on the concentration gradients of both protons and 
monocarboxylate ions. Thus, MCT4 [56] serves to gate the export of lactate, while MCT1 can facilitate both its import and export depending on the $\mathrm{pH}$ gradient [57].

In doing so they promote a metabolic interchange between glycolytic and oxidative tumor cells [58], as the lactate released by cancer cells is used by neighboring stromal cells as an energy source [59]. For example, endothelial cells use lactate both as a signaling molecule and as a metabolic intermediate in neo-angiogenesis [60]. Differences in the regulation of the expression and activity of lactate transporters support the intercellular lactate exchange model shown in Figure 2.

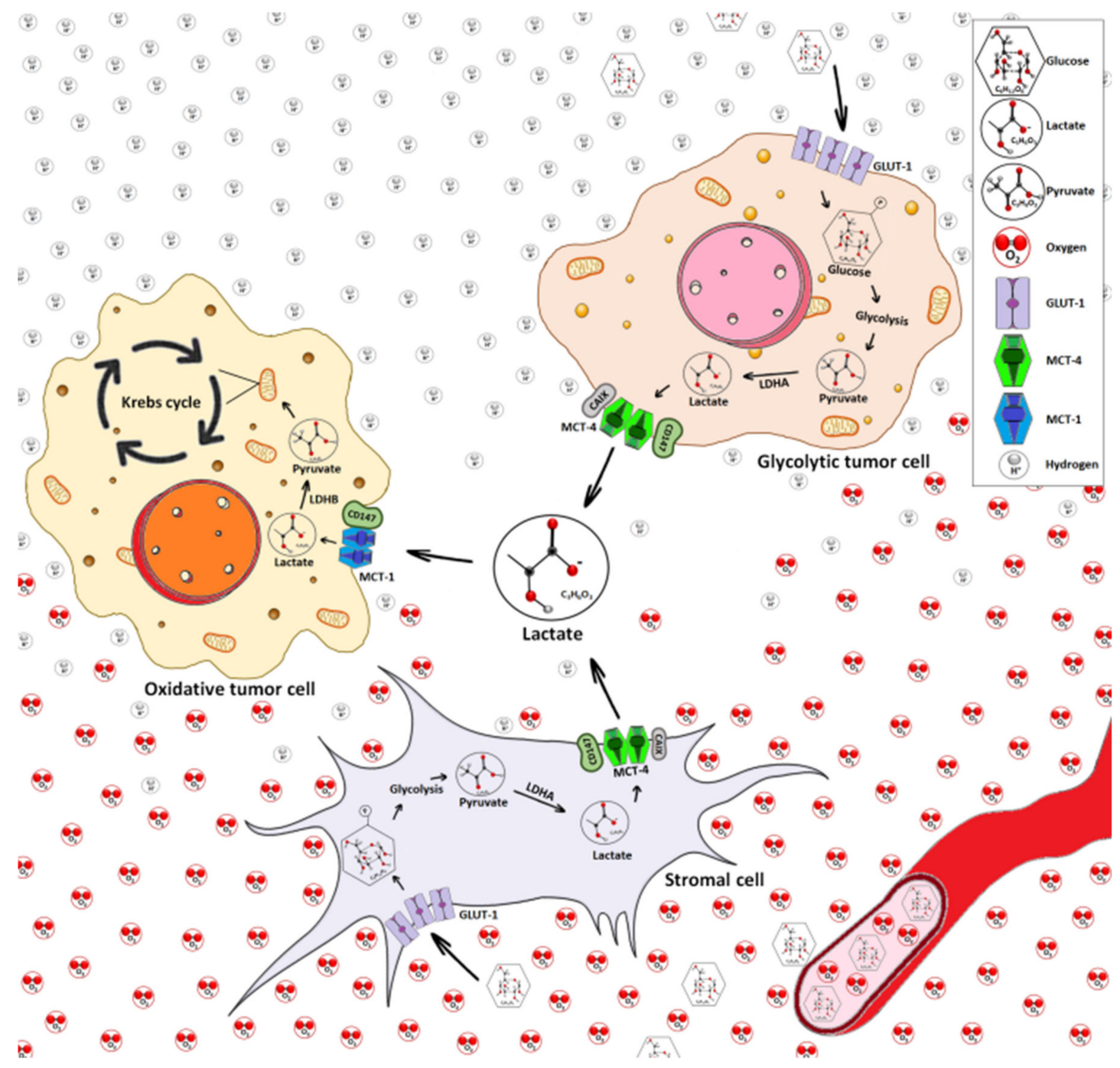

Figure 2. Intercellular lactate exchange in the tumor microenvironment (TME). The TME is a complex ultrastructure containing different cell types, including tumor cells, stromal cells, immune cells, blood vessels and cellular metabolites such as lactate. Oxidative tumor cells (orange nuclei) and stromal cells (gray cytoplasm) are supported by a favorable location with high nutritional and $\mathrm{O}_{2}$ availability. Oxidative tumor cells (orange nuclei) express MCT1 transporter which preferentially promotes lactate import. The glycolytic tumor cells (pink nuclei) produce lactate by the glycolytic pathway that culminates in the final reaction mediated by lactate dehydrogenase LDHA, and exhibit high expression of MCT4 favoring lactate export. Lactate can be used as an energetic source through its conversion to pyruvate via LDHB and then go to into the Krebs cycle for energy generation. Thus, the glycolytic tumor cell (pink nuclei), and stromal cell (gray) interchange of lactate with oxidative tumor cells (orange nuclei) increases tumor cell survival and proliferation. CD147: chaperone. CAIX: carbonic anhydrase IX. Made from the original idea [61]. 


\section{The Lactate Receptor GPR81 and other Modes of Lactate Transport}

Lactate also exerts its pro-tumoral activity independent of MCTs, by binding to its receptor, GPR81, at the cell surface [56]. Lactate signaling via GPR81 does not require $\mathrm{H}^{+}$or MCTs, nor is a conversion to pyruvate or an alteration in the intracellular $\mathrm{NADH} / \mathrm{NAD}^{+}$ratio a prerequisite.

GPR81 belongs to the hydroxy carboxylic acid receptor (HCAR) subfamily, which is composed of three members: HCAR1 (GPR81), HCAR2 (GPR109A) and HCAR3 (GPR109B) [62]. It was discovered by Ge et al. in 2008 [63] and was first identified in the plasma membranes of adipocytes. GPR81 acts synergistically with insulin to decrease intracellular cAMP levels and lipolysis in the fed state, with a clear link to obesity [64]. L-lactate is the receptor's natural ligand and has an EC50 of $\approx 5 \mathrm{mM}$. Recently, the lactate-GPR81 system has been implicated as a signaling mechanism in neuroprotection, angiogenesis and the regulation of neuronal firing [65-67]. A role for lactate via GPR81 binding has also been observed in infection, inflammation and the suppression of innate immune cell function $[68,69]$.

The expression of GPR81 on the membranes of cancer cells was first reported in 2014, in a study involving different cancer cell lines and tumor samples resected from pancreatic cancer patients [70]. Lactate signaling via GPR81 is especially unique from everything we have seen until now. The signaling through GPR81 does not require $\mathrm{H}^{+}$or MCT-driven import, nor does it require a conversion to pyruvate or alterations in the intracellular NADH/ NAD ${ }^{+}$ratio. Despite its negligible expression in benign cells, the receptor was shown to be upregulated in malignant cells derived from the same tissues. The 2014 study of Roland et al. [70] demonstrated that the silencing of GPR81 in pancreatic cancer cell cultures with high glycolytic ratios and high lactate concentrations in the media resulted in significantly reduced mitochondrial activity and obvious increases in cell death. The importance of GPR81 as a pro-tumorigenic element has also been determined in breast, hepatocellular and lung cancers and cervical squamous-cell carcinoma [71-73]. Recently, Xie et al. [74] reported that lactate itself induces the expression of GPR81 in cancer cells via transcriptional activation involving the Snail/EZH2/STAT3 transcriptional complex.

GPR81 may contribute substantially to tumor growth and proliferation by responding to lactate in the extracellular environment in an autocrine or a paracrine manner. In the former, lactate released by the tumor cells is taken up by GPR81 expressed on those cells. Alternatively, extracellular lactate may act on GPR81 expressed on the non-cancer cells located in the TME that support tumor growth [75], including immune cells (dendritic cells and macrophages), adipocytes and endothelial cells [69,76,77]. The presence of a high concentration of lactate in the extracellular environment of the tumor is associated with a poor prognosis [78]; thus, GPR81 signaling, whether autocrine or paracrine, is likely to be involved in the promotion of tumor growth and/or metastasis.

Finally, an alternative route for venting lactate anions from poorly perfused cells involves gap junctions assembled from connexin proteins. They form intercellular channels that couple the cytoplasms of neighboring cells into a syncytium and establish high conductance pathways for the passage of small molecules [79]. Several reports produced evidence that connexins can, in fact, facilitate late-stage disease in certain cancers [80]. In spheroids of PDACs (pancreatic ductal adenocarcinoma cells), researchers were able to demonstrate that connexin 43 (Cx43) channels are important conduits for dissipating lactate anions from glycolytic PDACs. Furthermore, lactate entry into the better-perfused recipient cells has a favorable alkalinizing effect and supplies substrate for oxidative phosphorylation. Cx43 is thus a novel target for influencing metabolite handling in junctional-coupled tumors [81].

The different modes and activities of the lactate transporters discussed herein are summarized in Figure 2.

\section{Lactate Exchange}

Solid tumors are typically nutrient-starved, as their rapid growth drives an increased rate of nutrient consumption further worsened by a deficient tumor vascular supply. To bypass these limitations, tumors have developed various nutrient-scavenging strategies, including lactate exchange [82]. Figure 2 depicts the exchange of lactate between tumor cells, stromal cells and the TME. 
Most tumors are heterogeneous, made up of oxidative cells, glycolytic cells and stromal cells. Their complex metabolic relationship includes the exchange of lactate in the form of metabolic symbiosis [83]. Oxidative tumor cells are located close to tumor blood vessels and predominantly oxidize lactate to pyruvate in a reaction catalyzed by LDHB, with the simultaneous output of NADH and $\mathrm{H}^{+}$. In addition to their favorable location allowing a high nutrient availability, these cells express MCT1 and are thus able to take up the lactate secreted into the TME by glycolytic tumor cells and stromal cells through their expression of MCT4 $[17,59]$. Because oxidative tumor cells preferentially use lactate as an oxidative fuel, they spare glucose such that it becomes available for both glycolytic tumor cells and stromal cells, via anaerobic and aerobic glycolysis, respectively [83]. Both glucose transporter-1 (GLUT-1) allowing cellular glucose uptake and MCT4 are induced in the distal hypoxic cells of a tumor, with a clear dependency on HIF-1- $\alpha$ [83].

\section{Lactate and Cancer-Related Genes}

A "triad" of transcription factors consisting of HIF- $1 \alpha$, c-MYC and p53 are largely responsible for the glycolytic phenotype in cancer [84]. In particular, the up-regulation of HIF-1 $\alpha$ and c-MYC together with the suppression of p53 induce a metabolic switch to glycolysis in cancer cells by inducing the overexpression of glycolytic enzyme by 2 to 500-fold [85]. Conversely, lactate, as an active metabolite of aerobic glycolysis and glutaminolysis, alters the transcriptional activity of several key oncogenes and other driver genes involved in metabolic reprograming, cell cycle regulation and proliferation [26]. San-Millan et al. 2020 [86] demonstrated that lactate acts as an oncometabolite in the MCF7 human breast cancer cell line, as it increases the transcriptional activity of MYC and that of PIK3CA, AKT1, HIF- $1 \alpha$ and BRCA1, all of which contribute to an upregulation of the glycolytic pathway in this cancer cell line $[87,88]$.

Among the oncogenes activated by lactate is MYC, a potent mediator of tumorigenesis whose deregulation has been found in a variety of cancers [89]. MYC participates in glucose metabolism by increasing the expression of the glucose transporter GLUT1 and by upregulating the expression of glycolytic enzymes, including hexokinase 2 (HK2), PFK-M1 and enolase 1 (ENO1) [90,91]. MYC also enhances expression of the M2 isoform of pyruvate kinase (PKM2), an enzyme essential for aerobic glycolysis and present in virtually all tumors [92], by promoting the expression of hnRNP splicing factors, as demonstrated in glioma [93].

During glycolysis, $\mathrm{NAD}^{+}$is reduced to NADH. The regeneration of $\mathrm{NAD}^{+}$and thus the maintenance of the glycolytic flux depends on LDHA, which converts the pyruvate derived from both the glycolytic and the glutaminolytic pathway into lactate [94]. The overexpression of MYC enhances LDHA expression, with the increased production of lactate then leading to extracellular acidification, as discussed above [95]. MYC also promotes lactate secretion, by enhancing the expression of MCT1 [5], and the uptake of glucose indirectly, by blocking the transcriptional function of MondoA, which in turn inhibits the thioredoxin-interacting protein (TXNIP), a negative regulator of glycolysis [96].

HIF1- $\alpha$, which is also overexpressed in tumor cells, increases the transcription of genes regulating glucose transport and glycolytic enzymes [97]. Moreover, it causes a metabolic reprogramming that leads to the Warburg effect and thus to lactate production. HIF1- $\alpha$ has been implicated in breast cancer tumor growth and metastasis, and in tumor aggressiveness associated with a poor prognosis $[86,98]$.

Mutations in the Ras oncogene are found in many types of human cancers and drive the metabolic phenotype of cancer cells toward aerobic glycolysis [99]. Ras activates the mammalian target of rapamycin (mTOR) via the PI3K-Akt-mTOR pathway, which promotes glycolysis by inducing HIFs [100,101].

Tumor suppressor p53 is a transcription factor that regulates diverse biological functions, including cellular energy metabolism. It plays a pivotal role in balancing glycolysis, which it inhibits, and oxphos [102], which it promotes [102], including by directly regulating LDHA expression at the transcriptional level. As such, the dysregulation of p53 is an important driver of the metabolic switch to glycolysis in cancer cells. Among the other critical functions of p53 are the control of 
cell proliferation, invasion and the induction of apoptosis [103]. As a potent negative regulator of HIF-1 $\alpha$, it blocks the latter's accumulation in normoxia and hypoxia [104] and induces inhibitory microRNA-107 [105].

Other transcription factors have also been implicated in the role of lactate in tumor metabolism. For example, in 2018, Li et al. [106] showed that the transcription factor sine oculis homeobox 1 (SIX1) can regulate the Warburg effect by binding to promoters and recruiting the histone acetyltransferases HBO1 and AIB1. These enzymes in turn induce the expression of LDHA and many other glycolytic genes (GLUT1, HK2, PFKL, ALDOA, GAPDH, PGK1, ENO1, PKM2) involved in the glycolysis pathway.

TWIST1, a transcription factor and master regulator of the epithelial-to-mesenchymal transition (EMT), promotes the invasion and metastasis of cancer cells. In pancreatic ductal adenocarcinoma, TWIST1 directly increases the transcription of several glycolytic genes, including GLUT1, HK2, ENO1 and PKM2. Transcriptional regulation by TWIST1 is not dependent on HIF1 $\alpha$ or c-Myc [107].

In a recent study, Zhang et al. [108], showed that the "lactylation" of histone lysine residues serves as an epigenetic modification that directly stimulates gene transcription in human and mouse cells. Among their novel findings was a dose-dependent increase in lysine lactylation (Kla) in response to exogenous L-lactate and that endogenous production of lactate is a key determinant of histone Kla levels. Bhagat et al. [109] also recently demonstrated that tumor-mediated lactate can elicit epigenomic reprograming - proven in pancreatic ductal adenocarcinoma. However, the influence of lactate on the cancerous epigenome is thus far poorly understood.

\section{Lactate as a Key Molecule in the "Immune Scape"}

The TME, through the actions of its stromal cells, is in a state of constant modification as the tumor progresses. As noted above, CAFs, tumor endothelial cells and immune cells make up the cellular components of the TME. On the one hand, innate (macrophages, neutrophils, dendritic cells, innate lymphoid cells, myeloid-derived suppressor cells and natural killer cells) and adaptive ( $\mathrm{T}$ and B cells) immune cells present in the TME are responsible for the detection and elimination of cancer cells [110]. On the other, the ability of tumor cells to secrete anti-inflammatory cytokines allows the recruitment of immunosuppressive cell populations to the TME, where they directly inhibit immune responses (Figure 3) [111,112].

In the tumor microenvironment some areas can reach up to $40 \mathrm{mM}$ lactate concentrations, which tumor cells can cope with [20]. The question is, how do infiltrating immune cells handle a lactate-rich microenvironment?

There is evidence of a harmful effect of high concentrations of lactate in the TME, including the tumor-infiltrating immune cells, but, paradoxically, immune cells contribute to intratumoral lactate production [113]. However, this contribution is relatively modest, as it depends on the number of immune cells recruited, their differentiation/activation statuses and whether they have become dysfunctional due to the immunosuppressive mechanisms of the tumor.

Lactate contributes to the immune escape of tumor cells by inducing the apoptosis of natural killer (NK) and natural killer T (NKT) cells, both of which exhibit antitumoral activity $[114,115]$.

Lactate concentrations $>20 \mathrm{mM}$ were shown to induce the apoptosis of both cell types, which may explain their smaller proportions in tumors with higher concentrations of lactate [116]. Lactate also blocks interferon (IFN)- $\gamma$ and interleukin (IL)-4 production by antitumoral NKT cells in the TME, via the inhibition of mTOR signaling, thereby preventing the activation of these immune cells [115]. Fisher et al. [21] showed that lactate inhibits T-cell proliferation and alters cytokine production through cultured cytolytic T lymphocytes. Lactate/Gpr81-induced immunosuppression also inhibits host defense against tumor growth $[71,90]$. 

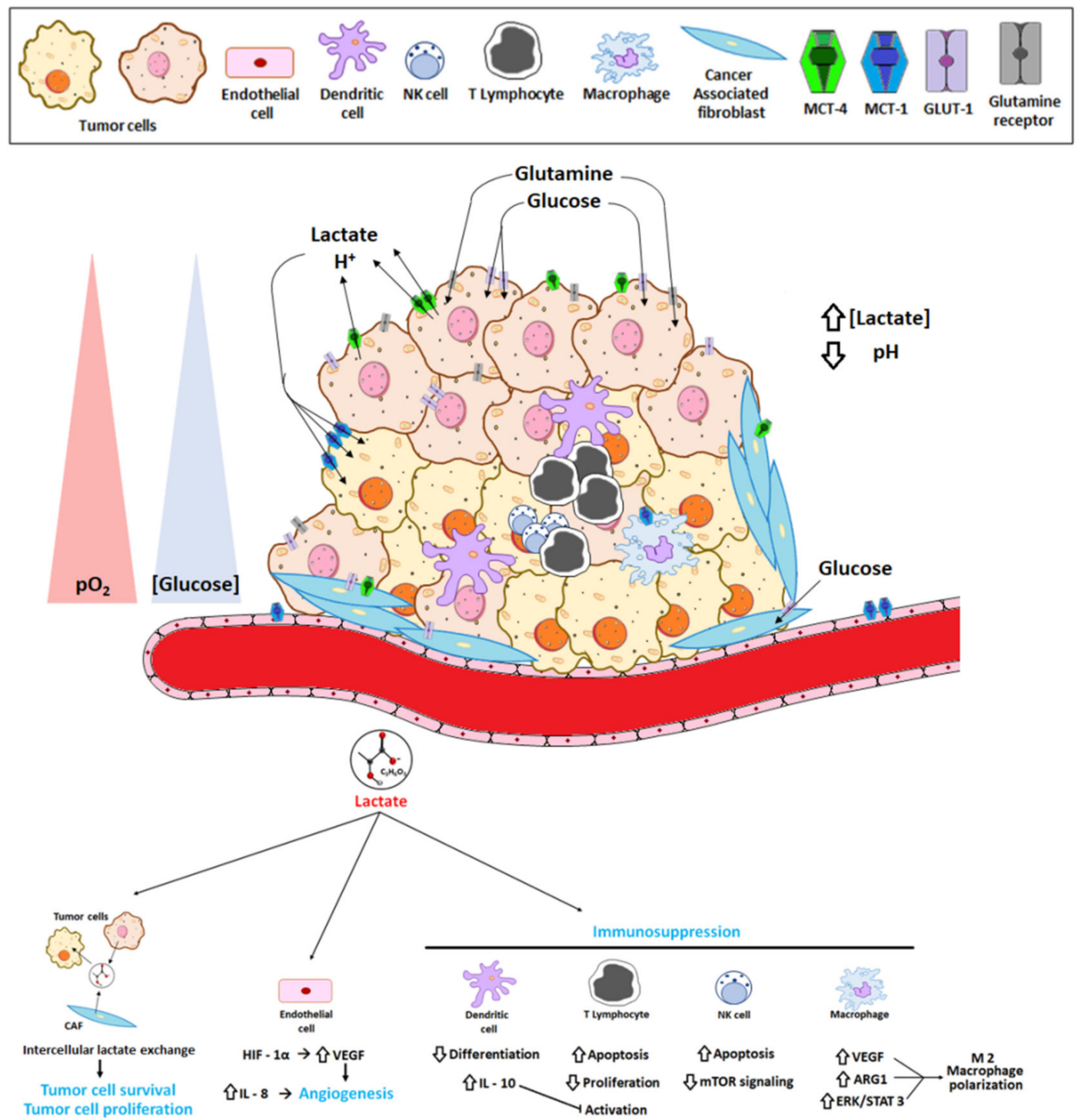

Figure 3. Effect of lactate on the tumor microenvironment (TME). Lactate secretion by tumors and stromal cells mainly acidifies the tumor microenvironment and creates a lactate interchange between them that increases tumor cell survival and proliferation. Lactate also stimulates tumor angiogenesis via endothelial cells and contributes to the immune scape by altering several immune infiltrating cells.

Dendritic cells (DC) are antigen-presenting cells that play a major role in immune responses. One of the main functions of DCs is the recognition of tumor cells, by processing and presenting tumor antigens through the MHC-II and MHC-I, leading in turn to the activation of CD4 ${ }^{+}$and CD8 ${ }^{+} \mathrm{T}$ lymphocytes, respectively, in response to environmental cytokines such as IL-12, TNF- $\alpha$ and IFN- $\gamma$ produced by NK and NKT cells and macrophages [117]. Lactate prevents DC differentiation and causes the cells to become tolerogenic, leading to an increase in the production of IL-10, a potent immuno-suppressive cytokine [118] that inhibits the production of proinflammatory cytokines such as IFN $\gamma, \mathrm{TNF} \alpha$, IL-1 $\beta$ and IL-6; moreover, IL-10 prevents DC maturation and T cell activation [119].

Lactate also promotes the development of myeloid-derived suppressor cells (MDSCs), a heterogeneous population of immature myeloid cells that are able suppress both innate and adaptive immunity by preventing the maturation of dendritic cells (DCs); suppressing natural killer (NK) cell cytotoxicity; inhibiting T cell activation; and favoring the differentiation of regulatory $\mathrm{T}$ cells and thus disturbing innate and adaptive immune responses [120]. 
In many cancers, tumor-associated macrophages (TAMs) are constantly recruited to the tumor environment by the CCL2 chemokine, which attracts CCR2+ monocytes circulating in the blood. Following their arrival in the TME and subsequent differentiation, the resulting TAMs contribute to neoplastic growth, invasion and metastatic diffusion by translating instructive signals delivered by transformed cells. Lactate in the TME is taken up by TAMs through their MCTs, which are located on the cell membranes. Among the lactate-induced responses are the HIF- $\alpha$-induced transcriptions of vascular endothelial growth factor (VEGF) and the metabolizing enzyme arginase-1 (ARG1), which promote TAM polarization [121]. The latter results in the expression of a set of genes that are common to M2-type macrophages, a specialized subset of TAMs that mediate in inflammation resolution and tissue remodeling. In a breast cancer model [122], lactate was shown to activate the ERK/STAT3 signaling pathway and thereby TAM polarization and M2 macrophage differentiation, which in turn promoted tumor proliferation, migration and angiogenesis.

Lactate is also involved in tumor evasion of the immune response, including via its receptor GPR81. In co-cultures of GPR81-expressing lung cancer cells and Jurkat $\mathrm{T}$ cells, both cell proliferation and IFN- $\gamma$ production by the latter were reduced compared to co-cultures with lung cancer cells lacking GPR81 [73]. Activation of the GPR81 receptor on the surface of lung cancer cells upregulates the membrane expression of PD-L1 to block immune responses to the tumor [86]. Similarly, the blockage of LDHA in tumor cells improves the efficacy of anti-programmed cell death-1 (PD1) therapy [116]. Brown et al. [123] showed that antigen-presenting DCs express GPR81, whose lactate-mediated activation suppresses the cell-surface expression of MHC-II, thereby compromising the ability of DCs to present tumor-cell antigens to T cells [123].

Taken together, these studies provide multiple lines of evidence that lactate is an important component of the TME, promoting tumor growth and immunosuppression and therefore carcinogenesis.

\section{Lactate in Tumor Metastasis}

As tumor cells proliferate, room must be made for their expansion, which requires degradation of the ECM, the invasion of local tissues and other processes. The acidification of the extracellular space that occurs following the transport of lactate to the TME modifies the binding properties of tumor cell surface integrins, improving their binding to ECM components and the subsequent migration of tumor cells $[9,124]$. Acidification also activates tumor-cell proteinases, such as matrix metalloproteinases-9 [125], cathepsin B and hyaluronidase-2, which degrade the surrounding matrix and promote tumor cell migration [126]. A decreased extracellular $\mathrm{pH}$ increases the density and length of tumor cell "invadopodia," responsible for the movements that support tumor cell invasion [127].

Evidence from mouse models of cancer suggests that neutralizing the external acidity of the tumor with oral buffers is an effective strategy for the prevention and inhibition of metastasis [128-130]. In fact, a recent study showed the association of combined chemotherapy and alkalization therapy with more favorable outcomes in patients with advanced and recurrent pancreatic cancer who had increased urine $\mathrm{pH}$ after alkalization therapy [131]. A pilot phase I clinical study by a research group from the University of Arizona examined the safety of the long-term consumption of sodium bicarbonate (ClinicalTrials.gov identifier: NCT02531919), but detailed results have yet to be reported.

A correlation between high concentrations of lactate in the TME and a greater propensity of tumors to metastasize has been reported [132,133]. Indeed, in different forms of human cancers the strong correlation between lactate levels and metastasis is well-established, including cervical cancer [134], head and neck cancer [20,135], colorectal adenocarcinoma [136] and gastric cancer [137]. For example, in cervical cancer a high lactate concentration correlates with poorer overall and disease-free survival [19].

Nonetheless, the mechanism underlying lactate's involvement in metastasis is not fully understood. In glioma cells, lactate induces the expression of transforming growth factor- $\beta 2$ (TGF $\beta 2$ ), a key regulator of glioma cell migration [138]. The addition of exogenous lactate to cultures of different cancer cell lines increases cell motility and random migration in a concentration-dependent manner [139]. In cells exposed to lactate, MCT1 mRNA and protein expression increase rapidly [140]. Clinical studies have 
shown that high-level MCT1 expression is associated with invasion in different cancers, including MCT1 in non-small-cell lung cancer [141] and MCT4 in melanoma [142]. Zhao et al. [143] proposed a decrease in NF- $\mathrm{kB}$ signaling coupled with MCT1 repression as a molecular mechanism to decrease osteosarcoma cell migration. A similar conclusion was reached in a study of cervix and breast cancer cells [144]. However, the pro-migratory activity of MCT1 is independent of its transporter activity, and the direct or indirect interaction of MCT1 with upstream components of the NF- $\mathrm{kB}$ signaling pathway may support its activity. Like the knockdown of MCT1, MCT4 knockdown seems to impair the migration and invasion of different cell lines [128,145]; Gallagher, S.M. et al. were able to demonstrate that MCT4 directly interacts with $\beta 1$-integrin at the lamellipodium of migrating cells [146]. Since integrin conformation is $\mathrm{pH}$-sensitive [147], the loss of MCT4 activity may locally modify the transmembrane $\mathrm{pH}$ gradient and therefore integrin signaling and cell adhesion.

Furthermore, CD147, a chaperone protein shared by MCT1 and MCT4, triggers cancer cell migration, invasion and metastasis, specifically through activation of matrix metalloproteinases (MMPs) [148]. As MCT1 and CD147, and MCT4 and CD147 are mutually stabilizing at the cell plasma membrane (Figure 2) [149], silencing of MCT1 or MCT4 might impair CD147 expression and function.

In their study of a murine model of breast tumors, Rizwan et al. [150] demonstrated that both LDHA expression and overall lactate production correlated with disease severity. The knockdown of LDHA was shown to delay metastasis and increase overall survival [150]. A link between LDHA/LDH5 overexpression and the epithelial-mesenchymal transition that characterizes metastatic disease was also recently reported [151].

The strong correlation of the lactate level in the TME with metastasis in different forms of human cancers, such as cervical cancer [134], head and neck cancer [20,135], colorectal adenocarcinoma [136] and gastric cancer, is well-established [137]. In cervical cancer, a higher lactate concentration correlates with poorer overall survival and a poorer disease-free survival [19].

\section{Lactate in Therapy Resistance}

The tumors of patients treated with antineoplastic agents frequently become drug resistant, in the form of either reduced responsiveness (primary resistance) or tumor relapse and progression (secondary resistance) [152]. Resistance has been attributed to cell-autonomous and non-cell autonomous mechanisms [153]. The TME has been implicated in the latter through various mechanisms, including hypoxia, extracellular acidity and lactate production [154]. The acidic TME seems to create a chemical barrier which means the extracellular accumulation of some chemotherapeutic drugs that usually enter the cells via passive diffusion, which limits their effects and activity. [155].

"Ion trapping" is a biological process that regulates passive permeability through the cellular membrane of charged compounds [156]. As a result, drugs can be impeded from reaching their targets because they get trapped on the wrong side of the cellular compartment. Both the intrinsic pKa values and the $\mathrm{pH}$ of the solution define the ionization of a molecule. Many small cancer drugs (weak bases or acids) are ionizable and therefore prone to ion trapping resistance [157]. Doxorubicin, a weakly basic anticancer drug (neutral in acidic conditions), can freely pass the membrane and enter the cell; it is then reduced and the ionized majority of the drug molecules are trapped on the extracellular side. The lack of efficacy of doxorubicin is associated with the ion trapping and low tumor tissue distribution [158]. On the other hand, an acidic extracellular environment favors the permeability of weakly acidic drugs and their cytotoxic activity. Anticancer drugs such as camptothecin, chlorambucil and melphalan are known to increase by extracellular acidosis. However, methotrexate, a weakly acidic drug, shows decreased cytotoxic activity under acidic conditions [159] due to breast cancer resistance protein (BCRP) that transports methotrexate, and in acidic conditions the electrostatic interaction between methotrexate and BCRP increases, which mediates drug efflux and consequently multidrug resistance [160]. Following the binding of lactate in the TME to MCT1, intracellular signaling pathways are activated that alter the expression of downstream effector molecules and allow tumor cells to become drug-resistant, via the AKT/mTOR, NF- $\mathrm{BB}$ and STAT3 signaling pathways. For example, activation of 
the mTOR pathway initiates metabolic symbiosis in cancer cells which thus become resistant to VEGF inhibitors [161]. The mechanism involves a switch by the tumor cells to the senescence-associated secretory phenotype (SASP), which confers non-cell-autonomous resistance. NF-kB signaling controls the expression of immunomodulatory and secretory factors, such as IL-6 and IL-8, which modulate the initiation and persistence of the SASP. In lymphoma, this phenotype is destroyed by NF-KB inhibition, leading to an escape from immunosurveillance by NK cells and p53 inactivation, and therefore to drug resistance [162]. In the TME, macrophages, neutrophils and CAFs are the major cell types that secrete IL-6 and IL-1 $\beta$; they are also responsible for STAT3 activation in tumor cells [163]. The activation of STAT3 and downstream effectors may confer drug resistance by initiating the EMT, suppressing epigenetic tumor suppressor miRNAs and enhancing the expression of antiapoptotic proteins $[164,165]$. Moreover, STAT3 expression in tumor cells may also enhance the expression of Rab family proteins, which facilitates exosome release to confer cisplatin resistance in ovarian cancer [166]. Acidic microenvironment is also involved in the increased rate of endosomal-lysosomal trafficking, and the increased release of extracellular vesicles (EVs) by tumor cells [167]. Thus, it is reasonable to think that cancer cells under the stress of the overly acidic microenvironment need to remove their toxic byproducts, and one of the mechanisms at their disposal is exosome elimination. Chemotherapeutic drugs such as cisplatin have been demonstrated to be eliminated via exosomes which thus participate in chemorresistance [168].

Tumor-derived exosomes have been detected in a wide variety of cancers and may also play significant roles in carcinogenesis and metastasis [169]. In cancer patients, a higher number of secreted exosomes correlates with a poor prognosis [170].

In in vitro models using NSCLC cell lines, Apicella et al. [171] showed that lactate is a key mediator of tumor cell resistance to therapy based on tyrosine kinase inhibitors (TKIs), particularly JNJ-605, a c-MET receptor tyrosine kinase inhibitor, and erlotinib, an epidermal growth factor receptor (EGFR) inhibitor [171]. Another study examined the metabolic inhibitors BEZ235, LY294002 and GDC0942 (as PI3K inhibitors) and GDC0980 (a dual PI3K/mTOR inhibitor) and was able to demonstrate the inhibition of breast cancer cell proliferation in high-glucose medium [172]. However, when lactate was used as the primary substrate, the cells were completely resistant to the inhibitors, suggesting that cancer cells able to rely on glycolysis by utilizing lactate are less sensitive to PI3K/mTOR inhibitors.

Lactate has also been implicated in radiotherapy resistance. In nude mice xenografted with human head and neck cutaneous squamous cell carcinoma cell lines and then treated with irradiation (4Gy) within 6 weeks, a high lactate concentration correlated with radioresistance [173].

\section{Therapeutic Strategies Targeting Lactate}

The findings discussed above provide strong evidence of a dual role for lactate in tumors, as a metabolic fuel and as a signaling molecule, thereby positioning lactate at the intersection of cancer initiation and progression. Targeting the aberrant lactate homeostasis of tumor cells offers a promising approach to cancer therapeutics, since any interference in the expression and/or functioning of the molecules that contribute to the deregulated glucose and/or glutamine metabolism will inevitably impact lactate production and release [174]. The intercellular exchange of lactate between oxidative and glycolytic tumor cells or tumor cells and stromal cells, (including endothelial cells and fibroblasts) can be targeted as well. The development of LDH and MCT inhibitory strategies may thus be promising avenues of research. In the following, we highlight recent findings obtained using available molecules directed at interfering with lactate production and transport, with a focus on those involving LDHs and MCTs.

\subsection{Targeting Lactate Production}

An effective therapeutic approach may be targeting LDHs (Table 1) that mediate the bidirectional conversion of pyruvate into lactate. Because LDHA is the predominant isoform expressed in glycolytic tumors, several LDHA-targeting compounds have been investigated. Among these, the ability of FX-11, 
a gossypol derivative (AT-101) [175]; galloflavin [176]; and N-hydroxyindole-based compounds [177] to preferentially inhibit LDHA has been demonstrated [178].

Table 1. Compounds to inhibit lactate production.

\begin{tabular}{|c|c|c|c|c|}
\hline Target & Drug & Type of Cancer or Cell/Animal Model & Research Phase & References \\
\hline \multirow{13}{*}{ LDH } & FX-11 & $\begin{array}{l}\text { B-lymphoid cells (P493, P198) } \\
\text { Xenograft model }\end{array}$ & Pre-clinical & [167] \\
\hline & Gossypol AT-10 & Multiple kinds of cancer & $\begin{array}{l}\text { Phase I and Phase } \\
\text { II clinical trials }\end{array}$ & {$[171,172]$} \\
\hline & Galloflavin & $\begin{array}{l}\text { Liver cancer (PLC/PRF/5) } \\
\text { Hepatocellular carcinoma }\end{array}$ & Pre-clinical & {$[168,174]$} \\
\hline & N-hydroxyindole-based compounds & $\begin{array}{l}\text { Colon (Caco-2, HCT116 and HT29) } \\
\text { Bladder (5637, HT1197, HT1376, RT4, } \\
\text { SW780, T24, TCCSUP and UM-UC-3) }\end{array}$ & Pre-clinical & [169] \\
\hline & FX866 & $\begin{array}{l}\text { Pancreatic cancer (P198) } \\
\text { Xenograft model }\end{array}$ & Pre-clinical & [167] \\
\hline & Oxamate & $\begin{array}{l}\text { Hepatocellular carcinoma } \\
\text { Medulloblastoma }\end{array}$ & Pre-clinical & {$[174,175]$} \\
\hline & $\begin{array}{l}2 \text { Thio-6-oxo1,6-dihydropyrinidine } \\
\text { (DHPMs) }\end{array}$ & $\begin{array}{l}\text { Pancreatic carcinoma } \\
\text { (MIA PaCa-2) } \\
\text { Mouse model }\end{array}$ & Pre-clinical & [176] \\
\hline & GNE-140 & $\begin{array}{c}\text { Colon adenocarcinoma (LS174T) } \\
\text { Mouse model } \\
\text { Pancreatic carcinoma (MIA PaCa-2) }\end{array}$ & Pre-clinical & {$[177,178]$} \\
\hline & Pyzazole based inhibitors & $\begin{array}{l}\text { Pancreatic carcinoma } \\
\text { (MIA PaCa-2) } \\
\text { A673 Sarcoma (A673) }\end{array}$ & Pre-clinical & [179] \\
\hline & $\begin{array}{l}\text { 1-(Phenylseleno)-4-(Trifluoromethyl) } \\
\text { Benzene (PSTMP) }\end{array}$ & $\begin{array}{l}\text { Large cell lung cancer (NCI-H460) } \\
\text { Breast cancer (MCF-7) } \\
\text { Hepatocellular carcinoma (Hep3B) } \\
\text { Malignan melanoma (A375) } \\
\text { Colorectal adenocarcinoma (HT29) } \\
\text { Murine lung cancer (LLC) }\end{array}$ & Pre-clinical & [180] \\
\hline & Compound 11 & Osteosarcoma (MG-63) & Pre-clinical & [181] \\
\hline & Compound $24 \mathrm{c}$ & Pancreas carcinoma (MiaPaCa-2) & Pre-clinical & [182] \\
\hline & $\begin{array}{l}\text { Peptides collections (QLYNL, } \\
\text { LIYNLL, IYNLLK, KWYNVA, } \\
\text { and KVVYNV) }\end{array}$ & None & In silico modeling & [183] \\
\hline
\end{tabular}

Notes: a ClinicalTrials.gov identifier: NCT01791595.

In tumor xenograft models, FX-11 efficiently inhibited the growth of P493 and P198 pancreatic cancer cells. In an alternative approach using a human lymphoma xenograft model, FK866, which hampers $\mathrm{NAD}^{+}$synthesis, was tested both alone and in combination with FX-11, and potently inhibited lymphoid cell proliferation [175]. These results provide strong evidence that LDHA is necessary for tumor progression [175].

Gossypol, also known as AT-101, is a nonselective inhibitor of LDH, whose antitumor activity has been attributed to its additional ability to inhibit the activities of anti-apoptotic Bcl-2 protein family members. It has been tested in several phase I and phase II clinical trials (Table 1), either as monotherapy or in combination with chemotherapy in several tumor types, but in the majority of studies the response rates were insignificant $[179,180]$.

Heat shock transcription factor 1 (HSF-1) regulates the expression of heat shock proteins (HSPs), which are essential for cell survival, and the heat shock response (HSR). In addition, HSF-1 regulates glucose metabolism by activating the expression of LDHA [181]. Galloflavin and oxamate, another inhibitor of LDH activity that directly competes with its natural substrate, were tested in a model of hepatocellular carcinoma (Table 1). The results indicated that LDH inhibition is an efficient way to dampen a constitutively activated HSR in cancer cells, by hindering the functions of the three major molecular chaperones (HSP-90, HSP-72 and HSP-27) involved in tumorigenesis. Furthermore, 
both compounds resulted in cell senescence [174]. However, oxamate has never been used in clinical trials because its activity requires concentrations in the millimolar range [182,183].

Other potent inhibitors of human LDH include 2-thio-6-oxo-1,6-dihydropyrimidine, with effective cellular in vitro cytotoxicity in pancreatic carcinoma cells (MIA PaCa-2 cell line) and in a mouse model of cancer [184]. High-throughput small-molecule screening using a library containing $\approx 2$ million compounds was conducted to identify small-molecule inhibitors of LDHA. One such inhibitor, GNE-140, efficiently inhibited murine B16 melanoma and human adenocarcinoma and pancreatic carcinoma cells in vitro (Table 1). The drug's activity was dependent on the metabolic activity of the cells $[185,186]$. However, to the best of our knowledge, no clinical trials of LHD small-molecule inhibitors have been registered to date.

Unfortunately, none of the above-discussed compounds nor pyrazole-based inhibitors of LDH [187] have progressed to the point of being clinically viable forms of treatment. Given the importance of lactate metabolism in different types of cancers, optimizing existing compounds while continuing the search for and development of new LDHA inhibitors would be a reasonable strategy.

A very promising novel compound (compound 11) was reported by Fang A et al. [188], who used docking-based virtual screening and biological assays. When tested in a MG-63 osteosarcoma cell line, compound 11 inhibited LDHA and induced apoptosis by decreasing lactate formation and extracellular acidification [188]. Nevertheless, further experiments with different types of cancers are needed to ensure the biological efficacy of this drug.

Recently, Kim et al. [189] identified several promising selenobenzene compounds with LDHA-inhibitory activity. The most potent was 1-(phenylseleno)-4(trifluoromethyl) benzene (PSTMB), which inhibited cell proliferation and induced apoptosis in several human cancer cell lines, including lung cancer (NCI-H460), breast cancer (MCF-7), hepatocellular carcinoma (Hep3B), malignant melanoma (A375) and colorectal adenocarcinoma (HT29) lines. PSTMB reduces both LDHA activity and lactate production under normoxic and hypoxic conditions, by inhibiting enzyme activity directly, rather than enzyme expression [189] (Table 1).

Zhou et al. [182] characterized a compound referred to as 24c, a novel potent LDHA inhibitor that interacts directly with the enzyme's binding pocket. Compound $24 \mathrm{c}$ was obtained by a hit-to-lead optimization using an in-house library. In the MiaPaCa-2 pancreatic carcinoma cell line, compound $24 \mathrm{c}$ resulted in dose-dependent reductions of cell growth and cell cycle arrest and apoptosis (Table 1). Furthermore, it suppressed tumor growth in a xenograft model [190]. These results suggest the use of compound 24c as a lead compound in the development of new, more potent LDHA inhibitors [190].

With the aid of in silico methods, Jafary F et al. [191] designed novel peptides that interfere with LDHA activity, by anchoring the enzyme's subunits such that tetramerization and therefore activity are blocked [191]. However, these peptides must be developed and then tested in in vitro before their biological action in vivo can be evaluated.

\subsection{Targeting Lactate Transporters}

Targeting MCTs is likely to have dramatic effects on intercellular lactate exchange (Figure 2). MCT1-specific inhibition damages lactate influx, forcing a cellular metabolic switch from the lactate that fuels oxphos to aerobic glycolysis, thereby indirectly causing the death of hypoxic cancer cells due to glucose deprivation $[61,83]$. MCT1 targeting can affect the intercellular lactate exchange, which is very important for cancer cell adaptation to glucose depletion $[61,83]$. In addition, the targeting of MCT1 weakens tumor resistance to anti-angiogenic therapy [192].

MCT inhibitors include AR-C155858 [193], which non-specifically targets MCT1 and MCT2, and SR13800, whose target is MCT1 [194]. In addition, promising preclinical success has been obtained with the AstraZeneca compound AZ3965, an inhibitor of both MCT1 and MCT2 but with 6-fold greater selectivity for MCT1 [195].

The in vitro anti-tumor activity of AZ3965 is mediated by a significant impairment of lactate production leading to massive tumor cell die-off [196]. AZ3965 was shown to be effective when 
tested in models of Burkitt's lymphoma, and breast, gastric and small-cell lung cancer $[194,195]$ and is currently the focus of a phase I/II clinical trial (ClinicalTrials. Gov NCT01791595) (Table 2). A possible drawback is that data from preclinical and retrospective analyses suggest that when MCT1 is inhibited, MCT4 is able to compensate for its function. However, Ždralevic, M. et al. [197] demonstrated that this mechanism also offers metabolic vulnerabilities for therapeutic interventions, via "ferroptosis"-induced cell death [197]. Intriguingly, in the only study examining the effect of AZD3965 on angiogenesis, the drug did not alter the vascularization of a small cell lung carcinoma xenograft [198].

In murine models of cancer, administration of the MCT inhibitor $\alpha$-cyano-4- hydroxycinnamate (CHC) decreased tumor growth by inducing necrosis in the tumor core, associated with the extinction of hypoxic tumor areas [83]. The authors proposed that while oxidative cancer cells adapt to MCT1 inhibition by switching to alternative substrates, glycolytic cancer cells cannot depend on lactate exchange for survival [83]. However, MCT1 inhibition interferes with other oxidative cancer cells, such as stromal cells, that take up additional lactate in the TME. While co-cultures of tumor cells and CAFs fuel cancer cell proliferation, either CHC administration or MCT1 knockdown is able to disrupt this relationship, hence impairing cancer cell proliferation [199]. Moreover, MCT1 targeting in endothelial and cancer cells, using a silencing approach or $\mathrm{CHC}$ administration, was shown to disrupt lactate-induced angiogenesis, both in vitro and in murine models of cancer in vivo [60,200] (Table 2).

Another novel selective MCT1 inhibitor is BAY-8002, which is six times more selective for MCT1 than for MCT2, has no activity against MCT4 and has no off-target effects [201].

Competition studies demonstrated the similar mechanisms of action of BAY-8002 and AZD3965, based on their mutual displacement. Moreover, cancer cells with inhibited MCT1 activity increase their levels of oxidative mitochondrial metabolism and become more sensitive to ETC complex I inhibitors, such as metformin, phenformin and BAY87-2243 [196,202,203], and to the GLS1 inhibitor bis-2-(5- phenylacetamido-1,3,4-thiadiazol-2-yl) ethyl sulfide (BPTES) (Table 2) [204]. Accordingly, the ability of MCT1 to transport additional exogenous compounds should be kept in mind, as inhibition of the enzyme may reduce/augment the toxic effects of these molecules [205]. In the development of combination treatments, the potential involvement of MCT1 in multidrug resistance should be taken into account [206]. 
Table 2. Compounds to inhibit lactate transport.

\begin{tabular}{|c|c|c|c|c|}
\hline Target & Drug & Type of Cancer or Cell/Animal Model & Research Phase & References \\
\hline \multirow{5}{*}{ MCT1 } & AR-C155858 & Murine breast cancer (4T1) & Pre-clinical & [186] \\
\hline & SR 13800 & Burkitt lymphoma (Raji) & Pre-clinical & [185] \\
\hline & AZD 3965 & $\begin{array}{c}\text { Human diffuse large B-cell lymphomas } \\
\text { (HBL-1 and TMD8) } \\
\text { Human B-cell lymphoma (WSU-CLCL-2 } \\
\text { and SU DHL10) } \\
\text { Lymphoblast (HT) } \\
\text { B-cell non-Hodgkin lymphoma } \\
\text { (Karpas-422 NHL) } \\
\text { Raji Burkitt's lymphoma cells }\end{array}$ & $\begin{array}{l}\text { Pre-clinical } \\
\text { Phase I/II of clinical trials a }\end{array}$ & {$[186,188,189]$} \\
\hline & $\alpha$ - cyano-4-hydroxycinnamate $(\mathrm{CHC})$ & $\begin{array}{l}\text { Colorectal cancer (HCT15 and RKO) } \\
\text { Murine cancer model }\end{array}$ & Pre-clinical & {$[82,192]$} \\
\hline & BAY-8002 & $\begin{array}{l}\text { Hematopoietic malignancies, Raji, and } \\
\text { Daudi Burkitt lymphoma cells }\end{array}$ & Pre-clinical & [193] \\
\hline \multirow{3}{*}{ MTC4 } & Diclofenac & Caco- 2 cell line & $\begin{array}{l}\text { FDA- Approved as } \\
\text { anti-inflammatory drug }\end{array}$ & [200] \\
\hline & Bindarit & Xenopus oocyte & Experimental Research & [201] \\
\hline & AZ93 & Wide range of cancer cells & Pre-clinical & [202] \\
\hline \multirow{2}{*}{ MCT1/MCT4 } & Syrosingopine & $\begin{array}{l}\text { HeLa, HAP1, HL60 cells, liver tumor } \\
\text { mouse model }\end{array}$ & Pre-clinical & [189] \\
\hline & Lonidamine & DB-1 melanoma cell & $\begin{array}{c}\text { Pre-clinical } \\
\text { Phase III of clinical trials } \\
\text { (prostate cancer) }^{b}\end{array}$ & [203] \\
\hline \multirow[b]{2}{*}{ CD147 } & pCMBS & $\begin{array}{c}\text { Molecular biology } \\
\text { (Xenopus oocyte, murine cells) }\end{array}$ & Experimental Research & [205] \\
\hline & AC-73 & $\begin{array}{l}\text { Hepatocellular carcinoma } \\
\quad \text { (SMMC-7721, Huh7) } \\
\text { Orthotopic transplant nude mouse model }\end{array}$ & Pre-clinical & [206] \\
\hline Metuzumab & $\begin{array}{l}\text { Xenograft models } \\
\text { (A549, NCI-H520) } \\
\text { Monkey model }\end{array}$ & Pre-clinical & [207] & \\
\hline
\end{tabular}

Notes: ${ }^{a}$ adult glioblastoma, phase II, ClinicalTrials.gov identifier: NCT00540722; lymphoma, phase II, ClinicalTrials.gov identifier: NCT00275431; adrenocortical carcinoma, phase II, ClinicalTrials.gov identifier: NCT00848016; leukemia, phase II, ClinicalTrials.gov identifier: NCT00286780; laryngeal cancer, phase II, ClinicalTrials.gov identifier: NCT01633541; small-cell lung cancer, phase II, ClinicalTrials.gov identifier: NCT00773955; prostate cancer, phase II, ClinicalTrials.gov identifier: NCT006666666; ${ }^{\text {b }}$ ClinicalTrials.gov identifier: NCT00435448. 
MCT4 mediates lactic acid efflux from glycolytic cancer cells and is therefore an important $\mathrm{pH}$ regulator [207]. The inhibition of MCT4 would acidify the cytosol of glycolytic cancer cells and thereby induce their death. MCT4 is highly expressed in many tumors, particularly in hypoxic regions of the fast-growing tumor mass, due to its HIF1-dependent expression. The disruption of lactate exchange between different cell populations by MCT4 knockdown may also offer an effective therapeutic strategy.

Among the selective inhibitors of MCT4 are diclofenac [208] and bindarit (2-[(1-benzyl1H-indazol-3-yl) methoxy]-2-methylpropanoic acid) [209] (Table 2). The AstraZeneca MCT4 inhibitor AZ93 reduces the proliferation of various cancer cell lines in which MCT1 has been inhibited as well [210]. Indeed, it may be that only the concurrent inhibition of MCT1 and MCT4 can impair tumor growth, especially under hypoxic conditions. In this context, syrosingopine, a dual inhibitor of MCT1 and MCT4, showed potential antitumor benefits in vivo [189]. Lonidamine, another dual inhibitor, was particularly effective in sensitizing tumors to other therapies [196,211] (Table 2). For example, additive or synergetic effects have been observed following MCT1, MCT2 or MCT4 inhibition in combination with chemotherapy [71,143,212] and radiotherapy [71].

Finally, MCT1 and MCT4 localization and maintenance at the plasma membrane are influenced by CD147/basigin, a member of the co-chaperone immunoglobulin-family. Targeting CD147 may therefore offer a novel strategy to inhibit the activity of both transporters. Among the agents tested thus far are an organomercurial compound, p-chloromercuribenzene sulfonate (pCMBS), which disrupts MCT association with CD147 [213]; AC-73, which targets CD147 dimerization [214]; and humanized anti-CD147 antibodies [215] (Table 2). However, CD147 is expressed in other tissues and can act as co-chaperone for other membrane proteins, such that its safety as an anti-cancer target must be carefully evaluated.

\section{Conclusions and Remarks}

In this review, we present an integrated assessment of the role of lactate in tumor development and growth. The Warburg effect and other alterations in tumor metabolism have been recognized as hallmarks of cancer for several decades, but the wide-ranging roles of lactate and acidosis in tumorigenesis have only recently been recognized.

Glycolytic cancer cells increase their uptake of glucose and nutrients and their production of lactate even under aerobic conditions. They are also able to adapt to hypoxic and low-nutrient microenvironments and engage in lactate exchange with the oxidative cancer cells adjacent to blood vessels and sustained by the high nutritional availability offered by this location. These cells are essential to rapid tumor progression. Our review also explored both lactate's ability to stimulate angiogenesis and the effects of lactate on immunosuppression and other immune cell functions.

Renewed interest in cancer metabolism during the last 15 years has alerted researchers to the potential of targeting tumor metabolism in the treatment of cancer. However, thus far, metabolic targeting approaches have been effective in the preclinical setting, but their translational impact remains limited. This may be a consequence of the metabolic heterogeneity of the cell populations that constitute the tumor bulk. Even in seemingly identical tumor tissues, the metabolic behavior of individual tumor cells differs, resulting in a complex metabolic mosaicism, with some cancer cells driven by oxphos and others by glycolysis. This preference may be caused by genetic heterogeneity of the tumor, low vs. high-nutrient perfusion, hypoxic vs. non-hypoxic exposure and/or by the consequences of a highly stroma-infiltrated tumor mass. The aggressiveness of tumors is derived in part from their higher metabolic plasticity, which no doubt has contributed to the failure of previous trials with antimetabolic drugs in single-agent administrations.

Driving tumor and stromal cells to adopt a more homogeneous metabolic phenotype through combinations of two or more drugs may thus be more successful. For example, anti-angiogenic drugs may generate a more hypoxic TME and therefore a more homogeneous metabolic phenotype. Targeting lactate metabolism in combination with immunotherapy to enhance the efficacy of the latter also holds promise. Using a murine melanoma model, Daneshmandi S. et al. [116] demonstrated that the 
blockage of LDHA increased the number and cytolytic activity of NK cells and cytotoxic T lymphocytes, resulting in reduced tumor growth, when initiated in combination with anti-PD-1 therapy [116].

Further studies of the metabolic pathways of tumor cells, the functions of the TME and the role of lactate interchange between cancer and non-cancer cells in vivo are still needed to deepen our understanding of the nature of cancer and to develop effective forms of therapy. The efficacy of newly designed specific anion transporters able to move lactate out of the extracellular space is currently under investigation. These novel compounds may be effective in Warburg or glutamine-dependent cells and in lactate-exploiting cells.

Funding: This work was supported by a grant from the Spanish government and the EU (FIS PI18/00441).

Acknowledgments: The authors thank the current and former members of our laboratory and our collaborators for their contributions to the anion transporters research and publications during the last years. The authors apologize for not being able to cite many important publications due to the limited space allotted for this review.

Conflicts of Interest: The authors declare that the research was conducted in the absence of any commercial or financial relationships that could be or become potential conflict of interest.

\section{References}

1. Raju, T.N. The Nobel Chronicles. 1922: Archilbald Vivian Hill (1886-1977), Otto Fritz Meyerfhoff (1884-1951). Lancet 1998, 352, 1396. [CrossRef]

2. Shampo, M.A.; Kyle, R.A. Otto Meyerhoff-Nobel Prize for studies of muscle metabolism. Mayo Clin. Proc. 1999, 74, 67. [CrossRef] [PubMed]

3. Philp, A.; Macdonald, A.L.; Watt, P.W. Lactate-A signal coordinating cell and systemic function. J. Exp. Biol. 2005, 208, 4561-4575. [CrossRef]

4. Hanahan, D.; Weinberg, R.A. Hallmarks of cancer: The next generation. Cell 2011, 144, 646-674. [CrossRef]

5. Warburg, O.; Wind, F.; Negelein, E. The metabolism of tumors in the body. J. Gen. Physiol. 1927, 8, 519-530. [CrossRef]

6. Cairns, R.A.; Harris, I.S.; Mak, T.W. Regulation of cancer cell metabolism. Nat. Rev. Cancer 2011, 11, 85-95. [CrossRef]

7. Vander Heiden, M.G.; Cantley, L.C.; Thompson, C.B. Understanding the Warburg effect: The metabolic requirements of cell proliferation. Science 2009, 324, 1029-1033. [CrossRef]

8. Damiani, C.; Colombo, R.; Gaglio, D.; Mastroianni, F.; Pescini, D.; Westerhoff, H.V.; Mauri, G.; Vanoni, M.; Alberghina, L. A metabolic core model elucidates how enhanced utilization of glucose and glutamine, with enhanced glutamine-dependent lactate production, promotes cancer cell growth: The Warburg effect. PLoS Comput. Biol. 2017, 13, e1005758. [CrossRef] [PubMed]

9. Webb, B.A.; Chimenti, M.; Jacobson, M.P.; Barber, D.L. Dysregulated pH: A perfect storm for cancer progression. Nat. Rev. Cancer 2011, 11, 671-677. [CrossRef] [PubMed]

10. DeBerardinis, R.J.; Cheng, T. Q's next: The diverse functions of glutamine in metabolism, cell biology and cancer. Oncogene 2010, 29, 313-324. [CrossRef] [PubMed]

11. Estrela, J.M.; Ortega, A.; Obrador, E. Glutathione in cancer biology and therapy. Crit. Rev. Clin. Lab. Sci. 2006, 43, 143-181. [CrossRef] [PubMed]

12. Faubert, B.; Li, K.Y.; Cai, L.; Hensley, C.T.; Kim, J.; Zacharias, L.G.; Yang, C.; Do, Q.N.; Doucette, S.; Burguete, D.; et al. Lactate metabolism in human lung tumors. Cell 2017, 171, 358-371. [CrossRef]

13. Dhup, S.; Dadhich, R.K.; Porporato, P.E.; Sonveaux, P. Multiple biological activities of lactic acid in cancer: Influences on tumor growth, angiogenesis and metastasis. Curr. Pharm. Des. 2012, 18, 1319-1330. [CrossRef] [PubMed]

14. San-Millan, I.; Brooks, G.A. Reexamining cancer metabolism: Lactate production for carcinogenesis could be the purpose and explanation of the Warburg Effect. Carcinogenesis 2017, 38, 119-133. [CrossRef]

15. Lyssiotis, C.A.; Kimmelman, A.C. Metabolic interactions in the tumor microenvironment. Trends Cell Biol. 2017, 27, 863-875. [CrossRef]

16. Pedrosa, L.; Esposito, F.; Thomson, T.M.; Maurel, J. The Tumor Microenvironment in Colorectal Cancer Therapy. Cancers 2019, 11, 1172. [CrossRef] 
17. Hinshaw, D.C.; Shevde, L.A. The tumor microenvironment innately modulates cancer progression. Cancer Res. 2019, 79, 4557-4566. [CrossRef] [PubMed]

18. Hanahan, D.; Coussens, L.M. Accessories to the crime: Functions of cells recruited to the tumor microenvironment. Cancer Cell. 2012, 21, 309-322. [CrossRef]

19. Walenta, S.; Wetterling, M.; Lehrke, M.; Schwickert, G.; Sundfør, K.; Rofstad, E.K.; Mueller-Klieser, W. High lactate levels predict likelihood of metastases, tumor recurrence, and restricted patient survival in human cervical cancers. Cancer Res. 2000, 60, 916-921. [PubMed]

20. Brizel, D.M.; Schroeder, T.; Scher, R.L.; Walenta, S.; Clough, R.W.; Dewhirst, M.W.; Mueller-Klieser, W. Elevated tumor lactate concentrations predict for an increased risk of metastases in head-and-neck cancer. Int. J. Radiat. Oncol. Biol. Phys. 2001, 51, 349-353. [CrossRef]

21. Fischer, K.; Hoffmann, P.; Voelkl, S.; Meidenbauer, N.; Ammer, J.; Edinger, M.; Gottfried, E.; Schwarz, S.; Rothe, G.; Hoves, S.; et al. Inhibitory effect of tumor cell-derived lactic acid on human T cells. Blood 2007, 109, 3812-3819. [CrossRef]

22. Tatum, J.L.; Kelloff, G.J.; Gillies, R.J.; Arbeit, J.M.; Brown, J.M.; Chao, K.S.; Chapman, J.D.; Eckelman, W.C.; Fyles, A.W.; Giaccia, A.J. Hypoxia: Importance in tumor biology, noninvasive measurement by imaging, and value of its measurement in the management of cancer therapy. Int. J. Radiat. Oncol. Biol. 2006, 82, 699-757. [CrossRef]

23. Hashim, A.I.; Zhang, X.; Wojtkowiak, J.W.; Martínez, G.V.; Gillies, R.J. Imaging pH and metastasis. NMR Biomed. 2011, 24, 582-591. [CrossRef]

24. Reshkin, S.J.; Greco, M.R.; Cardone, R.A. Role of $\mathrm{pHi}$, and proton transporters in oncogene-driven neoplastic transformation. Philos. Trans. R. Soc. B Biol. Sci. 2014, 369, 20130100. [CrossRef]

25. Oberhaensli, R.D.; Bore, P.J.; Rampling, R.P.; Hilton-Jones, D.; Hands, L.J.; Radda, G.K. Biochemical investigation of human tumors in vivo with phosphorus-31 magnetic resonance spectroscopy. Lancet 1986, 328, 8-11. [CrossRef]

26. Parks, S.K.; Chicha, J.; Pouysségur, J. Disrupting proton dynamics and energy metabolism for cancer therapy. Nat. Rev. Cancer 2013, 13, 611-623. [CrossRef]

27. Nuccitelli, R.; Deamer, D.W. Intracellular pH: Its measurement, regulation and utilization in cellular functions. Yale J. Biol Med. 1982, 55, 541-542.

28. Andrés, V.; Carreras, J.; Cussó, R. Regulation of muscle phosphofructokinase by physiological concentrations of bisphosphorylated hexoses: Effect of alkalinization. Biochem. Biophys. Res. Commun. 1990, 172, 328-334. [CrossRef]

29. Kuwata, F.; Suzuki, N.; Otsuka, K.; Taguchi, M.; Sasai, Y.; Wakino, H.; Ito, M.; Ebihara, S.; Suzuki, K. Enzymatic regulation of glycolysis and gluconeogenesis in rabbit periodontal ligament under various physiological pH conditions. J. Nihon Univ. Sch. Dent. 1991, 33, 81-90. [CrossRef]

30. Pedersen, S.F. The $\mathrm{Na}^{+} / \mathrm{H}^{+}$exchanger NHE1 in stress-induced signal transduction: Implications for cell proliferation and cell death. Pflug. Arch. 2006, 452, 249-259. [CrossRef]

31. White, K.A.; Grillo-Hill, B.K.; Barber, D.L. Cancer cell behaviors mediated by dysregulated pH dynamics at a glance. J. Cell Sci. 2017, 130, 663-669. [CrossRef]

32. Matsuyama, J.; Llopis, J.; Deveraux, Q.L.; Tsien, R.Y.; Redd, J.C. Changes in intramitochondrial and cytosolic pH: Early events that modulate caspase activation during apoptosis. Nat. Cell Biol. 2000, 2, 318-325. [CrossRef] [PubMed]

33. Huber, V.; Camisaschi, C.; Berzi, A.; Ferro, S.; Lugini, L.; Triulzi, T.; Tuccitto, A.; Tagliabue, E.; Castelli, C.; Rivoltini, L. Cancer acidity: An ultimate frontier of tumor immune escape and a novel target of immunomodulation. Semin. Cancer Biol. 2017, 43, 74-89. [CrossRef]

34. Pavlova, N.N.; Thompson, C.B. The emerging hallmarks of cancer metabolism. Cell Metab. 2016, 23, $27-47$. [CrossRef]

35. Robergs, R.A.; Ghiasvand, F.; Parker, D. Biochemistry of the exercise-induced metabolic acidosis. Am. J. Physiol. Regul. Integr. Comp. Physiol. 2004, 287, R502-R516. [CrossRef]

36. Stubbs, M.; Rodrigues, L.; Howe, F.A.; Wang, J.; Jeong, K.S.; Veech, R.L.; Griffiths, J.R. Metabolic consequences of a reversed $\mathrm{pH}$ gradient in rat tumors. Cancer Res. 1994, 54, 4011-4016.

37. Valvona, C.J.; Fillmore, H.L.; Nunn, P.B.; Pilkington, G.J. The regulation and function of lactate dehydrogenase A: Therapeutic potential in brain tumor. Brain Pathol. 2016, 26, 3-17. [CrossRef] [PubMed] 
38. Jin, L.; Chun, J.; Pan, C.; Alesi, G.N.; Li, D.; Magliocca, K.R.; Kang, Y.; Chen, Z.G.; Shin, D.M.; Khuri, F.R.; et al. Phosphorylation-mediated activation of LDHA promotes cancer cell invasion and tumour metastasis. Oncogene 2017, 36, 3797-3806. [CrossRef] [PubMed]

39. Li, S.; Gao, J.; Zhuang, X.; Zhao, C.; Hou, X.; Xing, X.; Chen, C.; Liu, Q.; Liu, S.; Luo, Y. Cyclin G2 inhibits the warburg effect and tumour progression by suppressing LDHA phosphorylation in glioma. Int. J. Biol. Sci. 2019, 15, 544-555. [CrossRef]

40. Ždralević, M.; Marchiq, I.; De Padua, M.M.C.; Parks, S.K.; Pouysségur, J. Metabolic plasticity in cancers-distinct role of glycolytic enzymes GPI, LDHs or membrane transporters MCTs. Front. Oncol. 2017, 7, 313. [CrossRef]

41. Xiao, X.; Huang, X.; Ye, F.; Chen, B.; Song, C.; Wen, J.; Zhang, Z.; Zheng, G.; Tang, H.; Xie, X. The miR-34a-LDHA axis regulates glucose metabolism and tumor growth in breast cancer. Sci. Rep. 2016, 6, 21735. [CrossRef]

42. Zhang, Z.; Li, Y.; Yan, X.; Song, Q.; Wang, G.; Hu, Y.; Jiao, S.; Wang, J. Pretreatment lactate dehydrogenase may predict outcome of advanced non-small-cell lung cancer patients treated with immune checkpoint inhibitors: A meta-analysis. Cancer Med. 2019, 8, 1467-1473. [CrossRef]

43. Lv, J.; Zhou, Z.; Wang, J.; Yu, H.; Lu, H.; Yuan, B.; Han, J.; Zhou, R.; Zhang, X.; Yang, X.; et al. Prognostic Value of Lactate Dehydrogenase Expression in Different Cancers: A Meta-Analysis. Am. J. Med. Sci. 2019, 358, 412-421. [CrossRef]

44. Dawson, D.M.; Goodfriend, T.L.; Kaplan, N.O. Lactic dehydrogenases: Functions of the two types rates of synthesis of the two major forms can be correlated with metabolic differentiation. Science 2013, 143, 929-933. [CrossRef]

45. Brisson, L.; Bański, P.; Sboarina, M.; Dethier, C.; Danhier, P.; Fontenille, M.-J.; Van Hée, V.F.; Vazeille, T.; Tardy, M.; Falces, J.; et al. Lactate dehydrogenase B controls lysosome activity and autophagy in cancer cells. Cancer Cell 2016, 30, 418-431. [CrossRef] [PubMed]

46. McCleland, M.L.; Adler, A.S.; Deming, L.; Cosino, E.; Lee, L.; Blackwood, E.M.; Solon, M.; Tao, J.; Li, L.; Shames, D.; et al. Lactate dehydrogenase B is required for the growth of KRAS-dependent lung adenocarcinomas. Clin. Cancer Res. 2013, 19, 773-784. [CrossRef] [PubMed]

47. Cheng, A.; Zhang, P.; Wang, B.; Yang, D.; Duan, X.; Jiang, Y.; Xu, T.; Jiang, Y.; Shi, J.; Ding, C.; et al. Aurora-A mediated phosphorylation of LDHB promotes glycolysis and tumor progression by relieving the substrate-inhibition effect. Nat. Commun. 2019, 10, 5566. [CrossRef]

48. Urbańska, K.; Orzechowski, A. Unappreciated Role of LDHA and LDHB to Control Apoptosis and Autophagy in Tumor Cells. Int. J. Mol. Sci. 2019, 20, 2085. [CrossRef]

49. Trivedi, B.; Danforth, W.H. Effect of $\mathrm{pH}$ on the kinetics of frog muscle phosphofructokinase. J. Biol. Chem. 1966, 241, 4110-4112.

50. Prado-Garcia, H.; Campa-Higareda, A.; Romero-Garcia, S. Lactic Acidosis in the Presence of Glucose Diminishes Warburg Effect in Lung Adenocarcinoma Cells. Front. Oncol. 2020, 10, 807. [CrossRef]

51. Blasberg, R.G.; Gelovani-Tjuvajev, J. In vivo molecular-genetic imaging. J. Cell. Biochem. 2002, 39, $231-238$. [CrossRef] [PubMed]

52. Gallagher, F.A.; Kettunen, M.I.; Day, S.E.; Hu, D.-E.; Ardenkjaer-Larsen, J.H.; Zandt, R.I.; Jensen, P.R.; Karlsson, M.; Golman, K.; Lerche, M.H.; et al. Magnetic resonance imaging of $\mathrm{pH}$ in vivo using hyperpolarized 13C-labelled bicarbonate. Nature 2008, 453, 940-943. [CrossRef]

53. Jones, R.S.; Morris, M.E. Monocarboxylate transporters: Therapeutic targets and prognostic factors in disease. Clin. Pharmacol. Ther. 2016, 100, 454-463. [CrossRef]

54. Spencer, T.L.; Lehninger, A.L. L-lactate transport in Ehrlich ascites-tumour cells. Biochem. J. 1976, 154, 405-414. [CrossRef]

55. Halestrap, A.P. Monocarboxylic acid transport. Compr. Physiol. 2013, 3, 1611-1643.

56. Payen, V.L.; Mina, E.; Van Hée, V.F.; Porporato, P.E.; Sonveaux, P. Monocarboxylate transporters in cancer. Mol. Metab. 2019, 33, 48-66. [CrossRef]

57. Eilertsen, M.; Andersen, S.; Al-Saad, S.; Kiselev, Y.; Donnem, T.; Stenvold, H.; Pettersen, I.; Al-Shibli, K.; Richardsen, E.; Busund, L.-T.; et al. Monocarboxylate transporters 1-4 in NSCLC: MCT1 is an independent prognostic marker for survival. PLoS ONE 2014, 9, e105038. [CrossRef]

58. Ippolito, L.; Morandi, A.; Giannoni, E.; Chiarug, P. Lactate: A Metabolic Driver in the Tumour Landscape. Trends Biochem. Sci. 2019, 44, 153-166. [CrossRef] 
59. Rattigan, Y.I.; Patel, B.B.; Ackerstaff, E.; Sukenick, G.; Koutcher, J.A.; Glod, J.W.; Banerjee, D. Lactate is a mediator of metabolic cooperation between stromal carcinoma associated fibroblasts and glycolytic tumor cells in the tumor microenvironment. Exp. Cell Res. 2012, 318, 326-335. [CrossRef]

60. Végran, F.; Boidot, R.; Michiels, C.; Sonveaux, P.; Feron, O. Lactate influx through the endothelial cell monocarboxylate transporter MCT1 supports an NF- $\mathrm{kB} / \mathrm{IL}-8$ pathway that drives tumor angiogenesis. Cancer Res. 2011, 71, 2550-2560. [CrossRef] [PubMed]

61. Spugnini, E.P.; Sonveaux, P.; Stock, C.; Perez-Sayans, M.; De Milito, A.; Avnet, S.; Garcìa, A.G.; Harguindey, S.; Fais, S. Proton channels and exchangers in cancer. Biochim. Biophys. Acta 2015, 1848, 2715-2726. [CrossRef]

62. Offermanns, S.; Colletti, S.L.; Lovenberg, T.W.; Semple, G.; Wise, A.; Ijzerman, A.P. International union of basic and clinical pharmacology. LXXXII: Nomenclature and classification of hydroxy-carboxylic acid receptors (GPR81, GPR109A, and GPR109B). Pharmacol. Rev. 2011, 63, 269-290. [CrossRef]

63. Ge, H.; Weiszmann, J.; Reagan, J.D.; Gupte, J.; Baribault, H.; Gyuris, T.; Chen, J.-L.; Tian, H.; Li, Y. Elucidation of signaling and functional activities of an orphan GPCR, GPR81. J. Lipid Res. 2008, 49, 797-803. [CrossRef] [PubMed]

64. Ahmed, K.; Tunaru, S.; Tang, C.; Müller, M.; Gille, A.; Sassmann, A.; Hanson, J.; Offermanns, S. An autocrine lactate loop mediates insulin-dependent inhibition of lipolysis through GPR81. Cell Metab. 2010, 11, 311-319. [CrossRef]

65. Castillo, X.; Rosafio, K.; Wyss, M.T.; Drandarov, K.; Buck, A.; Pellerin, L.; Weber, B.; Hirt, L. A probable dual mode of action for both L- and D-lactate neuroprotection in cerebral ischemia. J. Cereb. Blood Flow Metab. 2015, 35, 1561-1569. [CrossRef]

66. Morland, C.; Andersson, K.A.; Haugen, Ø.P.; Hadzic, A.; Kleppa, L.; Gille, A.; Rinholm, J.E.; Palibrk, V.; Diget, E.H.; Kennedy, L.H.; et al. Exercise induces cerebral VEGF and angiogenesis via the lactate receptor HCAR1. Nat. Commun. 2017, 8, 15557. [CrossRef]

67. Madaan, A.; Chaudhari, P.; Nadeau-Vallée, M.; Hamel, D.; Zhu, T.; Mitchell, G.; Samuels, M.; Pundir, S.; Dabouz, R.; Cheng, C.W.H.; et al. Müller cell-localized G-protein-coupled receptor 81 (Hydroxycarboxylic Acid Receptor 1) regulates inner retinal vasculature via Norrin/Wnt pathways. Am. J. Pathol. 2019, 189, 1878-1896. [CrossRef]

68. Hoque, R.; Farooq, A.; Ghani, A.; Gorelick, F.; Mehal, W.Z. Lactate reduces liver and pancreatic injury in toll-like receptor- and inflammasome-mediated inflammation via GPR81-mediated suppression of innate immunity. Gastroenterology. 2014, 146, 1763-1774. [CrossRef]

69. Ranganathan, P.; Shanmugam, A.; Swafford, D.; Suryawanshi, A.; Bhattacharjee, P.; Hussein, M.S.; Koni, P.A.; Prasad, P.D.; Kurago, Z.B.; Thangaraju, M.; et al. GPR81, a cell-surface receptor for lactate, regulates intestinal homeostasis and protects mice from experimental colitis. J. Immunol. 2018, 200, 1781-1789. [CrossRef]

70. Roland, C.L.; Arumugam, T.; Deng, D.; Liu, S.H.; Philip, B.; Gomez, S.; Burns, W.R.; Ramachandran, V.; Wang, H.; Cruz-Monserrate, Z.; et al. Cell surface lactate receptor GPR81 is crucial for cancer cell survival. Cancer Res. 2014, 74, 5301-5310. [CrossRef]

71. Lee, Y.J.; Shin, K.J.; Park, S.-A.; Park, K.S.; Park, S.; Heo, K.; Seo, Y.-K.; Noh, D.-Y.; Ryu, S.H.; Suh, P.-G. G-protein-coupled receptor 81 promotes a malignant phenotype in breast cancer through angiogenic factor secretion. Oncotarget 2016, 7, 70898-70911. [CrossRef]

72. Lee, H.W.; Park, J.Y.; Hwang, I.; Jang, B.K.; Park, K.; Kang, Y.N. Clinicopathologic significance of G protein-coupled receptor 81 in hepatocellular carcinoma. Int. J. Cancer Res. Ther. 2017, 2, 1-6.

73. Feng, J.; Yang, H.; Zhang, Y.; Wei, H.; Zhu, Z.; Zhu, B.; Yang, M.; Cao, W.; Wang, L.; Wu, Z. Tumor cell-derived lactate induces TAZ-dependent upregulation of PD-L1 through GPR81 in human lung cancer cells. Oncogene 2017, 36, 5829-5839. [CrossRef]

74. Xie, Q.; Zhu, Z.; He, Y.; Zhang, Z.; Zhang, Y.; Wang, Y.; Luo, J.; Peng, T.; Cheng, F.; Gao, J.; et al. A lactate-induced Snail/ STAT3 pathway drives GPR81 expression in lung cancer cells. Biochim. Biophys. Acta Mol. Basis Dis. 2020, 1866, 165576. [CrossRef]

75. Brown, T.P.; Ganapathy, V. Lactate/GPR81 signaling and proton motive force in cancer: Role in angiogenesis, immune escape, nutrition, and Warburg phenomenon. Pharmacol. Ther. 2020, 206, 107451. [CrossRef]

76. Liu, C.; Wu, J.; Zhu, J.; Kuei, C.; Yu, J.; Shelton, J.; Sutton, S.W.; Li, X.; Yun, S.J.; Mirzadegan, T.; et al. Lactate inhibits lipolysis in fat cells through activation of an orphan G-protein-coupled receptor, GPR81. J. Biol. Chem. 2009, 284, 2811-2822. [CrossRef] 
77. Wallenius, K.; Thalén, P.; Björkman, J.-A.; Johannesson, P.; Wiseman, J.; Böttcher, G.; Fjellström, O.; Oakes, N.D. Involvement of the metabolic sensor GPR81 in cardiovascular control. JCI Insight. 2017, 2, e92564. [CrossRef]

78. Sun, S.; Li, H.; Chen, J.; Qian, Q. Lactic acid: No longer an inert and end-product of glycolysis. Physiology 2017, 32, 453-463. [CrossRef]

79. Kumar, N.M.; Gilula, N.B. The gap junction communication channel. Cell 1996, 84, 381-388. [CrossRef]

80. Zhang, A.; Hitomi, M.; Bar-Shain, N.; Dalimov, Z.; Ellis, L.; Velpula, K.K.; Fraizer, G.C.; Gourdie, R.G.; Lathia, J.D. Connexin 43 expression is associated with increased malignancy in prostate cancer cell lines and functions to promote migration. Oncotarget 2015, 6, 11640-11651. [CrossRef]

81. Dovmark, T.H.; Saccomano, M.; Hulikova, A.; Alves, F.; Swietach, P. Connexin-43 channels are a pathway for discharging lactate from glycolytic pancreatic ductal adenocarcinoma cells. Oncogene 2017, 36, 4538-4550. [CrossRef]

82. Baek, G.; Tse, Y.F.; Hu, Z.; Cox, D.; Buboltz, N.; McCue, P.; Yeo, C.J.; White, M.A.; DeBerardinis, R.J.; Knudsen, E.S.; et al. MCT4 defines a glycolytic subtype of pancreatic cancer with poor prognosis and unique metabolic dependencies. Cell Rep. 2014, 9, 2233-2249. [CrossRef]

83. Sonveaux, P.; Végran, F.; Schroeder, T.; Wergin, M.C.; Verrax, J.; Rabbani, Z.N.; De Saedeleer, C.J.; Kennedy, K.M.; Diepart, C.; Jordan, B.F.; et al. Targeting lactate-fueled respiration selectively kills hypoxic tumor cells in mice. J. Clin. Investig. 2008, 118, 3930-3942. [CrossRef]

84. Koppenol, W.H.; Bounds, P.L.; Dang, C.V. Otto Warburg's contributions to current concepts of cancer metabolism. Nat. Rev. Cancer 2011, 11, 325-337. [CrossRef]

85. Moreno-Sánchez, R.; Rodríguez-Enríquez, S.; Marín-Hernández, A.; Saavedra, E. Energy metabolism in tumor cells. FEBS J. 2007, 274, 1393-1418. [CrossRef]

86. San-Millán, I.; Julian, C.G.; Matarazzo, C.; Martinez, J.; Brooks, G.A. Is lactate an oncometabolite? evidence supporting a role for Lactate in the regulation of transcriptional activity of cancer-related genes in MCF7 breast cancer cells. Front. Oncol. 2020, 9, 1536. [CrossRef]

87. Kim, J.W.; Zeller, K.I.; Wang, Y.; Jegga, A.G.; Aronow, B.J.; O’Donnell, K.A.; Dang, C.V. Evaluation of myc E-box phylogenetic footprints in glycolytic genes by chromatin immunoprecipitation assays. Mol. Cell Biol. 2004, 24, 5923-5936. [CrossRef] [PubMed]

88. Dang, C.V.; Kim, J.W.; Gao, P.; Yustein, J. The interplay between MYC and HIF in cancer. Nat. Rev. Cancer 2008, 8, 51-56. [CrossRef]

89. Meyer, N.; Penn, L.Z. Reflecting on 25 years with MYC. Nat. Rev. Cancer 2008, 8, 976-990. [CrossRef]

90. Osthus, R.C.; Shim, H.; Kim, S.; Li, Q.; Reddy, R.; Mukherjee, M.; Xu, Y.; Wonsey, D.R.; Lee, L.A.; Dang, C.V. Deregulation of glucose transporter 1 and glycolytic gene expression by c-Myc. J. Biol. Chem. 2000, 275, 21797-21800. [CrossRef]

91. Kim, J.W.; Gao, P.; Liu, Y.C.; Semenza, G.L.; Dang, C.V. Hypoxia-inducible factor 1 and dysregulated c-Myc cooperatively induce vascular endothelial growth factor and metabolic switches hexokinase 2 and pyruvate dehydrogenase kinase 1. Mol. Cell Biol. 2007, 27, 7381-7393. [CrossRef]

92. Israelsen, W.J.; Vander Heiden, M.G. Pyruvate kinase: Function, regulation and role in cancer. Semin. Cell Dev. Biol. 2015, 43, 43-51. [CrossRef]

93. Luan, W.; Wang, Y.; Chen, X.; Shi, Y.; Wang, J.; Zhang, J.; Qian, J.; Li, R.; Tao, T.; Wei, W.; et al. PKM2 promotes glucose metabolism and cell growth in gliomas through a mechanism involving a let-7a/c-Myc/ hnRNPA1 feedback loop. Oncotarget 2015, 6, 13006-13018. [CrossRef]

94. Wise, D.R.; DeBerardinis, R.J.; Mancuso, A.; Sayed, N.; Zhang, X.-Y.; Pfeiffer, H.K.; Nissim, I.; Daikhin, E.; Yudkoff, M.; McMahon, S.B.; et al. Myc regulates a transcriptional program that stimulates mitochondrial glutaminolysis and leads to glutamine addiction. Proc. Natl. Acad. Sci. USA 2008, 105, 18782-18787. [CrossRef]

95. Maya-Mendoza, A.; Ostrakova, J.; Kosar, M.; Hall, A.; Duskova, P.; Mistrik, M.; Merchut-Maya, J.M.; Hodny, Z.; Bartkova, J.; Christensen, C.; et al. Myc and Ras oncogenes engage different energy metabolism programs and evoke distinct patterns of oxidative and DNA replication stress. Mol. Oncol. 2015, 9, 601-616. [CrossRef]

96. Shen, L.; O'Shea, J.M.; Kaadige, M.R.; Cunha, S.; Wilde, B.R.; Cohen, A.L.; Welm, A.L.; Ayer, D.E. Metabolic reprogramming in triple-negative breast cancer through Myc suppression of TXNIP. Proc. Natl. Acad. Sci. USA 2015, 112, 5425-5430. [CrossRef] 
97. Nagao, A.; Kobayashi, M.; Koyasu, S.; Chow, C.C.T.; Harada, H. HIF-1-Dependent Reprogramming of Glucose Metabolic Pathway of Cancer Cells and Its Therapeutic Significance. Int. J. Mol. Sci. 2019, 20, 238. [CrossRef] [PubMed]

98. Gilkes, D.M.; Semenza, G.L. Role of hypoxia-inducible factors in breast cancer metastasis. Future Oncol. 2013, 9, 1623-1636. [CrossRef]

99. Hu, Y.; Lu, W.; Chen, G.; Wang, P.; Chen, Z.; Zhou, Y.; Ogasawara, M.; Trachootham, D.; Feng, L.; Pelicano, H.; et al. K-ras (G12V) transformation leads to mitochondrial dysfunction and a metabolic switch from oxidative phosphorylation to glycolysis. Cell Res. 2012, 22, 399-412. [CrossRef]

100. Hoxhaj, G.; Mannin, B.D. The PI3K-AKT network at the interface of oncogenic signaling and cancer metabolism. Nat. Rev. Cancer 2020, 20, 74-88. [CrossRef]

101. Pylayeva-Gupta, Y.; Grabocka, E.; Bar-Sagi, D. RAS oncogenes: Weaving a tumorigenic web. Nat. Rev. Cancer 2011, 11, 761-774. [CrossRef]

102. Ma, W.; Sung, H.J.; Park, J.Y.; Matoba, S.; Hwang, P.M. A pivotal role for p53: Balancing aerobic respiration and glycolysis. J. Bioenergy Biomembr. 2007, 39, 243-246. [CrossRef]

103. Zhou, Y.; Niu, W.; Luo, Y.; Li, H.; Xie, Y.; Wang, H.; Liu, Y.; Fan, S.; Li, Z.; Xiong, W.; et al. p53/Lactate dehydrogenase $\mathrm{A}$ axis negatively regulates aerobic glycolysis and tumor progression in breast cancer expressing wild-type p53. Cancer Sci. 2019, 110, 939-949. [CrossRef]

104. Yang, J.; Ahmed, A.; Poon, E.; Perusinghe, N.; Brandon, A.D.H.; Box, G.; Valenti, M.; Eccles, S.; Rouschop, K.M.A.; Wouters, B.G.; et al. Small-molecule activation of p53 blocks hypoxia-inducible factor 1alpha and vascular endothelial growth factor expression in vivo and leads to tumor cell apoptosis in normoxia and hypoxia. Mol. Cell. Biol. 2009, 29, 2243-2253. [CrossRef]

105. Yamakuchi, M.; Lotterman, C.D.; Bao, C.; Hruban, R.H.; Karim, B.; Mendell, J.T.; Huso, D.; Lowenstein, C.J. p53-induced microRNA-107 inhibits HIF-1 and tumor angiogenesis. Proc. Natl. Acad. Sci. USA 2010, 107, 6334-6339. [CrossRef]

106. Li, L.; Liang, Y.; Kang, L.; Liu, Y.; Gao, S.; Chen, S.; Li, Y.; You, W.; Dong, Q.; Hong, T.; et al. Transcriptional regulation of the Warburg effect in cancer by SIX1. Cancer Cell. 2018, 33, 368-385.e7. [CrossRef]

107. Wang, X.-X.; Yin, G.-Q.; Zhang, Z.-H.; Rong, Z.-H.; Wang, Z.-Y.; Du, D.-D.; Wang, Y.-D.; Gao, R.-X.; Xian, G.-Z. TWIST1 transcriptionally regulates glycolytic genes to promote the Warburg metabolism in pancreatic cancer. Exp. Cell Res. 2020, 386, 111713. [CrossRef]

108. Zhang, D.; Tang, Z.; Huang, H.; Zhou, G.; Cui, C.; Weng, Y.; Liu, W.; Kim, S.; Lee, S.; Perez-Neut, M.; et al. Metabolic regulation of gene expression by histone lactylation. Nature 2019, 574, 575-580. [CrossRef]

109. Bhagat, T.D.; Von Ahrens, D.; Dawlaty, M.; Zou, Y.; Baddour, J.; Achreja, A.; Zhao, H.; Yang, L.; Patel, B.; Kwak, C.; et al. Lactate-mediated epigenetic reprogramming regulates formation of human pancreatic cancer-associated fibroblasts. Elife 2019, 8, e50663. [CrossRef] [PubMed]

110. Xia, A.L.; Xu, Y.; Lu, X.J. Cancer immunotherapy: Challenges and clinical applications. J. Med. Genet. 2019, 56, 1-3. [CrossRef]

111. Zou, W. Immunosuppressive networks in the tumour environment and their therapeutic relevance. Nat. Rev. Cancer 2005, 5, 263-274. [CrossRef]

112. Rabinovich, G.A.; Gabrilovich, D.; Sotomayor, E.M. Immunosuppressive strategies that are mediated by tumor cells. Annu. Rev. Immunol. 2007, 25, 267-296. [CrossRef]

113. Romero-Garcia, S.; Moreno-Altamirano, M.M.B.; Prado-Garcia, H.; Sánchez-García, F.J. Lactate Contribution to the Tumor Microenvironment: Mechanisms, effects on immune Cells and Therapeutic Relevance. Front. Immunol. 2016, 7, 52. [CrossRef]

114. Harmon, C.; Robinson, M.W.; Hand, F.; AlMuaili, D.; Mentor, K.; Houlihan, D.D.; Hoti, E.; Lynch, L.; Geoghegan, J.; O'Farrelly, C. Lactate-mediated acidification of tumor microenvironment induces apoptosis of liver-resident NK cells in colorectal liver metastasis. Cancer Immunol. Res. 2019, 7, 335-346. [CrossRef]

115. Kumar, A.; Pyaram, K.; Yarosz, E.L.; Hong, H.; Lyssiotis, C.A.; Giri, S.; Chang, C.-H. Enhanced oxidative phosphorylation in NKT cells is essential for their survival and function. Proc. Natl. Acad. Sci. USA 2019, 116, 7439-7448. [CrossRef]

116. Daneshmandi, S.; Wegiel, B.; Seth, P. Blockade of lactate dehydrogenase-A (LDH-A) improves efficacy of anti-programmed cell death-1 (PD-1) therapy in melanoma. Cancers 2019, 11, 450. [CrossRef] [PubMed]

117. Kim, B.; Kim, T.H. Fundamental role of dendritic cells in inducing Th2 responses. Korean J. Intern. Med. 2018, 33, 483-489. [CrossRef] 
118. Nasi, A.; Fekete, T.; Krishnamurthy, A.; Snowden, S.; Rajnavölgyi, E.; Catrina, A.I.; Wheelock, C.E.; Vivar, N.; Rethi, B. Dendritic cell reprogramming by endogenously produced lactic acid. J. Immunol. 2013, 191, 3090-3099. [CrossRef]

119. Zhao, S.; Wu, D.; Wu, P.; Wang, Z.; Huang, J.; Gao, J.X. Serum IL-10 predicts worse outcome in cancer patients: A meta-analysis. PLoS ONE 2015, 10, e0139598. [CrossRef]

120. Morrot, A.; Da Fonseca, L.M.; Salustiano, E.J.; Gentile, L.B.; Conde, L.; Filardy, A.A.; Franklim, T.N.; Da Costa, K.M.; Freire-De-Lima, C.G.; Freire-De-Lima, L. Metabolic symbiosis and immunomodulation: How tumor cell-derived lactate may disturb innate and adaptive immune responses. Front. Oncol. 2018, 8, 81. [CrossRef]

121. Bronte, V. Tumor cells hijack macrophages via lactic acid. Immunol. Cell Biol. 2014, 92, 647-649. [CrossRef] [PubMed]

122. Mu, X.; Shi, W.; Xu, Y.; Xu, C.; Zhao, T.; Geng, B.; Yang, J.; Pan, J.; Hu, S.; Zhang, C.; et al. Tumor-derived lactate induces M2 macrophage polarization via the activation of the ERK/STAT3 signaling pathway in breast cancer. Cell Cycle. 2018, 17, 428-438. [CrossRef]

123. Brown, T.; Ramachandran, S.; Offermanns, S.; Ganapathy, V. The lactate receptor Gpr81 on non-cancer cells promotes an immunosuppressive phenotype in the tumor microenvironment. Cancer Res. 2019, 79. [CrossRef]

124. Böhme, I.; Bosserhoff, A.K. Acidic tumor microenvironment in human melanoma pigment Cell. Melanoma Res. 2016, 29, 508-523. [CrossRef]

125. Putney, L.K.; Barber, D.L. Expression profile of genes regulated by activity of the Na-H exchanger NHE1. BMC Genom. 2004, 5, 46. [CrossRef]

126. Bourguignon, L.Y.; Singleton, P.A.; Diedrich, F.; Stern, R.; Gilad, E. CD44 interaction with Na + -H+ exchanger (NHE1) creates acidic microenvironments leading to hyaluronidase-2 and cathepsin B activation and breast tumor cell invasion. J. Biol. Chem. 2004, 279, 26991-27007. [CrossRef]

127. Busco, G.; Cardone, R.A.; Greco, M.R.; Bellizzi, A.; Colella, M.; Antelmi, E.; Mancini, M.T.; Dell'Aquila, M.E.; Casavola, V.; Paradiso, A.; et al. NHE1 promotes invadopodial ECM proteolysis through acidification of the peri-invadopodial space. FASEB J. 2010, 24, 3903-3915. [CrossRef]

128. Robey, I.F.; Baggett, B.K.; Kirkpatrick, N.D.; Roe, D.J.; Dosescu, J.; Sloane, B.F.; Hashim, A.I.; Morse, D.L.; Raghunand, N.; Gatenby, R.A.; et al. Bicarbonate increases tumor $\mathrm{pH}$ and inhibits spontaneous metastases. Cancer Res. 2009, 69, 2260-2268. [CrossRef]

129. Ibrahim-Hashim, A.; Abrahams, D.; Enriquez-Navas, P.M.; Luddy, K.; Gatenby, R.A.; Gillies, R.J. Tris-base buffer: A promising new inhibitor for cancer progression and metastasis. Cancer Med. 2017, 6, 1720-1729. [CrossRef] [PubMed]

130. Abumanhal-Masarweh, H.; Koren, L.; Zinger, A.; Yaari, Z.; Krinsky, N.; Kaneti, G.; Dahan, N.; Lupu-Haber, Y.; Suss-Toby, E.; Weiss-Messer, E.; et al. Sodium bicarbonate nanoparticles modulate the tumor $\mathrm{pH}$ and enhance the cellular uptake of doxorubicin. J. Control. Release. 2019, 296, 1-13. [CrossRef]

131. Hamaguchi, R.; Narui, R.; Wada, H. Effects of alkalization therapy on chemotherapy outcomes in metastatic or recurrent pancreatic cancer. Anticancer Res. 2020, 40, 873-880. [CrossRef]

132. Walenta, S.; Mueller-Klieser, W.F. Lactate: Mirror and motor of tumor malignancy. Semin. Radiat. Oncol. 2004, 14, 267-274. [CrossRef]

133. Lemma, S.; Di Pompo, G.; Porporato, P.E.; Sboarina, M.; Russell, S.; Gillies, R.J.; Baldini, N.; Sonveaux, P.; Avnet, S. MDA-MB-231 breast cancer cells fuel osteoclast metabolism and activity: A new rationale for the pathogenesis of osteolytic bone metastases. Biochim. Biophys. Acta Mol. Basis Dis. 2017, 1863, 3254-3264. [CrossRef] [PubMed]

134. Schwickert, G.; Walenta, S.; Sundfør, K.; Rofstad, E.K.; Mueller-Klieser, W. Correlation of high lactate levels in human cervical cancer with incidence of metastasis. Cancer Res. 1995, 55, 4757-4759. [PubMed]

135. Walenta, S.; Salameh, A.; Lyng, H.; Evensen, J.F.; Mitze, M.; Rofstad, E.K.; Mueller-Klieser, W. Correlation of high lactate levels in head and neck tumors with incidence of metastasis. Am. J. Pathol. 1997, 150, 409-415.

136. Walenta, S.; Chau, T.-V.; Schroeder, T.; Lehr, H.-A.; Kunz-Schughart, L.A.; Fuerst, A.; Mueller-Klieser, W. Metabolic classification of human rectal adenocarcinomas: A novel guideline for clinical oncologists? J. Cancer Res. Clin. Oncol. 2003, 129, 321-326. [CrossRef] 
137. Hur, H.; Xuan, Y.; Kim, Y.B.; Lee, G.; Shim, W.; Yun, J.; Ham, I.-H.; Han, S.-U. Expression of pyruvate dehydrogenase kinase-1 in gastric cancer as a potential therapeutic target. Int. J. Oncol. 2013, 42, 44-54. [CrossRef]

138. Baumann, F.; Leukel, P.; Doerfelt, A.; Beier, C.P.; Dettmer, K.; Oefner, P.J. Lactate promotes glioma migration by TGF-beta2-dependent regulation of matrix metalloproteinase-2. Neuro Oncol. 2009, 11, 368-380. [CrossRef]

139. Goetze, K.; Walenta, S.; Ksiazkiewicz, M.; Kunz-Schughart, L.A.; Mueller-Klieser, W. Lactate enhances motility of tumor cells and inhibits monocyte migration and cytokine release. Int. J. Oncol. 2011, 39, $453-463$. [CrossRef]

140. Hashimoto, T.; Hussien, R.; Oommen, S.; Gohil, K.; Brooks, G.A. Lactate sensitive transcription factor network in L6 cells: Activation of MCT1 and mitochondrial biogenesis. FASEB J. 2007, 21, 2602-2612. [CrossRef]

141. Geum-Hwa, L.; Do-Sung, K.; Myung, C.J.; Soo-Wan, C.; Hyung-Ryong, K.; Han-Jung, C. Lysyl oxidase-like-1 enhances lung metastasis when lactate accumulation and monocarboxylate transporter expression are involved. Oncol. Lett. 2011, 2, 831-838.

142. Pinheiro, C.; Miranda-Gonçalves, V.; Longatto-Filho, A.; Vicente, A.L.S.A.; Berardinelli, G.N.; Scapulatempo-Neto, C.; Costa, R.F.A.; Viana, C.R.; Reis, R.M.; Baltazar, M.D.F.M.; et al. The metabolic microenvironment of melanomas: Prognostic value of MCT1 and MCT4. Cell Cycle. 2016, 15, 1462-1470. [CrossRef]

143. Zhao, Z.; Wu, M.-S.; Zou, C.; Tang, Q.; Lu, J.; Liu, D.; Wu, Y.; Yin, J.; Xie, X.; Shen, J.; et al. Downregulation of MCT1 inhibits tumor growth, metastasis and enhances chemotherapeutic efficacy in osteosarcoma through regulation of the NF- $\kappa$ B pathway. Cancer Lett. 2014, 342, 150-158. [CrossRef]

144. Payen, V.L.; Hsu, M.Y.; Rädecke, K.S.; Wyart, E.; Vazeille, T.; Bouzin, C.; Porporato, P.E.; Sonveaux, P. Monocarboxylate transporter MCT1 promotes tumor metastasis independently of its activity as a lactate transporter. Cancer Res. 2017, 77, 5591-5601. [CrossRef]

145. Kong, S.C.; Nøhr-Nielsen, A.; Zeeberg, K.; Reshkin, S.J.; Hoffmann, E.K.; Novak, I.; Pedersen, S.F. Monocarboxylate transporters MCT1 and MCT4 regulate migration and invasion of pancreatic ductal adenocarcinoma cells. Pancreas 2016, 45, 1036-1047. [CrossRef] [PubMed]

146. Gallagher, S.M.; Castorino, J.J.; Philp, N.J. Interaction of monocarboxylate transporter 4 with beta1-integrin and its role in cell migration. Am. J. Physiol. Cell Physiol. 2009, 296, C414-C421. [CrossRef]

147. Schwab, A.; Fabian, A.; Hanley, P.J.; Stock, C. Role of ion channels and transporters in cell migration. Physiol. Rev. 2012, 92, 1865-1913. [CrossRef]

148. Kumar, D.; Vetrivel, U.; Parameswaran, S.; Subramanian, K.K. Structural insights on druggable hotspots in CD147: A bull's eye view. Life Sci. 2019, 224, 76-87. [CrossRef]

149. Morais-Santos, F.; Miranda-Gonçalves, V.; Pinheiro, S.; Vieira, A.F.; Paredes, J.; Schmitt, F.C.; Baltazar, F.; Pinheiro, C. Differential sensitivities to lactate transport inhibitors of breast cancer cell lines. Endocr. Relat. Cancer. 2013, 21, 27-38. [CrossRef]

150. Rizwan, A.; Serganova, I.; Khanin, R.; Karabeber, H.; Ni, X.; Thakur, S.B.; Zakian, K.L.; Blasberg, R.; Koutcher, J.A. Relationships between LDH-A, lactate, and metastases in $4 \mathrm{~T} 1$ breast tumors. Clin. Cancer Res. 2013, 19, 5158-5169. [CrossRef]

151. Zhao, J.; Huang, X.; Xu, Z.; Dai, J.; He, H.; Zhu, Y.; Wang, H. LDHA promotes tumor metastasis by facilitating epithelial mesenchymal transition in renal cell carcinoma. Mol. Med. Rep. 2017, 16, 8335-8344. [CrossRef]

152. Pérez-Tomás, R. Multidrug resistance: Retrospect and prospects in anti-cancer drug treatment. Curr. Med. Chem. 2006, 13, 1859-1876. [CrossRef]

153. Amoedo, N.D.; Obre, E.; Rossignol, R. Drug discovery strategies in the field of tumor energy metabolism: Limitations by metabolic flexibility and metabolic resistance to chemotherapy. Biochim. Biophys. Acta Bioenergy 2017, 1858, 674-685. [CrossRef]

154. Qu, Y.; Dou, B.; Tan, H.; Feng, Y.; Wang, N.; Wang, D. Tumor microenvironment driven non-cell-autonomous resistance to antineoplastic treatment. Mol. Cancer. 2019, 18, 1-16. [CrossRef]

155. Kolosenko, I.; Avnet, S.; Baldini, N.; Viklund, J.; De Milito, A. Therapeutic implications of tumor interstitial acidification. Semin. Cancer Biol. 2017, 43, 119-133. [CrossRef]

156. Gillies, R.; Pilot, C.; Marunaka, Y.; Fais, S. Targeting acidity in cancer and diabetes. Biochim. Biophys. Acta Rev. Cancer 2019, 1871, 273-280. [CrossRef]

157. Wojtkowiak, J.W.; Verduzco, D.; Schramm, K.J.; Gillies, R.J. Drug resistance and cellular adaptation to tumor acidic pH microenvironment. Mol. Pharm. 2011, 8, 2032-2038. [CrossRef] 
158. Tredan, O.; Galmarini, C.M.; Patel, K.; Tannock, I.F. Drug resistance and the solid tumor microenvironment. J. Natl. Cancer Inst. 2007, 99, 1441-1454. [CrossRef]

159. Avnet, S.; Lemma, S.; Cortini, M.; Pellegrini, P.; Perut, F.; Zini, N.; Kusuzaki, K.; Chano, T.; Grisendi, G.; Dominici, M.; et al. Altered $\mathrm{pH}$ gradient at the plasma membrane of osteosarcoma cells is a key mechanism of drug resistance. Oncotarget 2016, 7, 63408-63423. [CrossRef] [PubMed]

160. Li, L.; Sham, Y.Y.; Bikadi, Z.; Elmquist, W.F. pH-Dependent transport of pemetrexed by breast cancer resistance protein. Drug Metab. Dispos. 2011, 39, 1478-1485. [CrossRef] [PubMed]

161. Allen, E.; Miéville, P.; Warren, C.M.; Saghafinia, S.; Elizabeth, A.; Peng, M.-W.; Hanahan, D. Metabolic Symbiosis Enables Adaptive Resistance to Anti-angiogenic Therapy that Is Dependent on mTOR Signaling. Cell Rep. 2016, 15, 1144-1160. [CrossRef]

162. Chien, Y.; Scuoppo, C.; Wang, X.; Fang, X.; Balgley, B.; Bolden, J.E.; Premsrirut, P.; Luo, W.; Chicas, A.; Lee, C.S.; et al. Control of the senescence-associated secretory phenotype by NF- $\mathrm{B}$ promotes senescence and enhances chemosensitivity. Genes Dev. 2011, 25, 2125-2136. [CrossRef]

163. Samavati, L.; Rastogi, R.; Du, W.; Huttemann, M.; Fite, A.; Franchi, L. STAT3 tyrosine phosphorylation is critical for interleukin 1 beta and interleukin-6 production in response to lipopolysaccharide and live bacteria. Mol. Immunol. 2009, 46, 1867-1877. [CrossRef]

164. Wang, L.; Zhang, F.; Cui, J.Y.; Chen, L.; Chen, Y.T.; Liu, B.W. CAFs enhance paclitaxel resistance by inducing EMT through the IL-6/JAK2/STAT3 pathway. Oncol. Rep. 2018, 39, 2081-2090. [CrossRef] [PubMed]

165. Yin, Y.; Yao, S.; Hu, Y.; Feng, Y.; Li, M.; Bian, Z.; Zhang, J.; Qin, Y.; Qi, X.; Zhou, L.; et al. The Immune-microenvironment Confers Chemoresistance of Colorectal Cancer through Macrophage-Derived IL6. Clin. Cancer Res. 2017, 23, 7375-7387. [CrossRef] [PubMed]

166. Dorayappan, K.D.P.; Wanner, R.; Wallbillich, J.J.; Saini, U.; Zingarelli, R.; Suarez, A.A.; Cohn, D.E.; Selvendiran, K. Hypoxia-induced exosomes contribute to a more aggressive and chemoresistant ovarian cancer phenotype: A novel mechanism linking STAT3/Rab proteins. Oncogene 2018, 37, 3806-3821. [CrossRef]

167. Logozzi, M.; Angelini, D.F.; Iessi, E.; Mizzoni, D.; Di Raimo, R.; Federici, C.; Lugini, L.; Borsellino, G.; Gentiluccii, A.; Pierella, F.; et al. Increased PSA expression on prostate cancer exosomes in in vitro condition and in cancer patients. Cancer Lett. 2017, 403, 318-329. [CrossRef]

168. Federici, C.; Petrucci, F.; Caimi, S.; Cesolini, A.; Logozzi, M.; Borghi, M.; D’Ilio, S.; Lugini, L.; Violante, N.; Azzarito, T.; et al. Exosome release and low $\mathrm{pH}$ belong to a framework of resistance of human melanoma cells to cisplatin. PLoS ONE 2014, 9, e88193. [CrossRef] [PubMed]

169. Zhao, H.; Yang, L.; Baddour, J.; Achreja, A.; Bernard, V.; Moss, T.; Marini, J.C.; Tudawe, T.; Seviour, E.G.; Lucas, F.A.S.; et al. Tumor microenvironment derived exosomes pleiotropically modulate cancer cell metabolism. Elife 2016, 5, e10250. [CrossRef]

170. Kim, H.; Song, K.; Park, Y.; Kang, Y.; Lee, Y.; Lee, K.; Ryu, K.; Bae, J.; Kim, S. Elevated levels of circulating platelet microparticles, VEGF, IL-6 and RANTES in patients with gastric cancer: Possible role of a metastasis predictor. Eur. J. Cancer. 2003, 39, 184-191. [CrossRef]

171. Apicella, M.; Giannoni, E.; Fiore, S.; Ferrari, K.J.; Fernández-Pérez, D.; Isella, C.; Granchi, C.; Minutolo, F.; Sottile, A.; Comoglio, P.M.; et al. Increased lactate secretion by cancer cells sustains non-cell-autonomous adaptive resistance to MET and EGFR targeted therapies. Cell Metab. 2018, 28, 848-865. [CrossRef] [PubMed]

172. Park, S.; Chang, C.-Y.; Safi, R.; Liu, X.; Baldi, R.; Jasper, J.S.; Anderson, G.R.; Liu, T.; Rathmell, J.C.; Dewhirst, M.W.; et al. ERR $\alpha$-regulated lactate metabolism contributes to resistance to targeted therapies in breast cancer. Cell Rep. 2016, 15, 323-335. [CrossRef]

173. Quennet, V.; Yaromina, A.; Zips, D.; Rosner, A.; Walenta, S.; Baumann, M.; Mueller-Klieser, W. Tumor lactate content predicts for response to fractionated irradiation of human squamous cell carcinomas in nude mice. Radiother. Oncol. 2006, 81, 130-135. [CrossRef]

174. Janku, F.; Yap, T.A.; Meric-Bernstam, F. Targeting the PI3K pathway in cancer: Are we making headway? Nat. Rev. Clin. Oncol. 2018, 15, 273-291. [CrossRef]

175. Le, A.; Cooper, C.R.; Gouw, A.M.; Dinavahi, R.; Maitra, A.; Deck, L.M.; Royer, R.E.; Jagt, D.L.V.; Semenza, G.L.; Dang, C.V. Inhibition of lactate dehydrogenase-A induces oxidative stress and inhibits tumor progression. Proc. Natl. Acad. Sci. USA 2010, 107, 2037-2042. [CrossRef]

176. Farabegoli, F.; Vettraino, M.; Manerba, M.; Fiume, L.; Roberti, M.; Di Stefano, G. Galloflavin, a new lactate dehydrogenase inhibitor, induces the death of human breast cancer cells with different glycolytic attitude by affecting distinct signaling pathways. Eur. J. Pharm. Sci. 2012, 47, 729-738. [CrossRef] 
177. Lea, M.A.; Guzman, Y.; Desbordes, C. Inhibition of growth by combined treatment with inhibitors of lactate dehydrogenase and either phenformin or inhibitors of 6Phosphofructo-2-kinase/Fructose-2,6-bisphosphatase 3. Anticancer Res. 2016, 36, 1479-1488.

178. Doherty, J.R.; Cleveland, J.L. Targeting lactate metabolism for cancer therapeutics. J. Clin. Investig. 2013, 123, 3685-3692. [CrossRef]

179. Baggstrom, M.Q.; Qi, Y.; Koczywas, M.; Argiris, A.; Johnson, E.A.; Millward, M.J.; Murphy, S.C.; Erlichman, C.; Rudin, C.M.; Govindan, R. A phase II study of AT-101 (Gossypol) in chemotherapy-sensitive recurrent extensive-stage small cell lung cancer. J. Thorac. Oncol. 2011, 6, 1757-1760. [CrossRef]

180. Heist, R.S.; Fain, J.; Chinnasami, B.; Khan, W.; Molina, J.R.; Sequist, L.V.; Temel, J.S.; Fidias, P.; Brainerd, V.; Leopold, L.; et al. Phase I/II study of AT-101 with topotecan in relapsed and refractory small cell lung cancer. J. Thorac. Oncol. 2010, 5, 1637-1643. [CrossRef] [PubMed]

181. Zhao, Y.H.; Zhou, M.; Liu, H.; Ding, Y.; Khong, H.T.; Yu, D.; Fodstad, O.; Tan, M. Upregulation of lactate dehydrogenase A by ErbB2 through heat shock factor 1 promotes breast cancer cell glycolysis and growth. Oncogene 2009, 28, 3689-3701. [CrossRef]

182. Manerba, M.; Di Ianni, L.; Govoni, M.; Roberti, M.; Recanatini, M.; Di Stefano, G. LDH inhibition impacts on heat shock response and induces senescence of hepatocellular carcinoma cells. Eur. J. Pharm. Sci. 2017, 105, 91-98. [CrossRef] [PubMed]

183. Valvona, C.J.; Fillmore, H.L. Oxamate, but not selective targeting of LDH-A, inhibits medulloblastoma cell glycolysis, growth and motility. Brain Sci. 2018, 8, 56. [CrossRef]

184. Purkey, H.E.; Robarge, K.; Chen, J.; Chen, Z.; Corson, L.B.; Ding, C.Z.; DiPasquale, A.G.; Dragovich, P.S.; Eigenbrot, C.; Evangelista, M.; et al. Cell Active Hydroxylactam Inhibitors of Human Lactate Dehydrogenase with Oral Bioavailability in Mice. ACS Med. Chem. Lett. 2016, 7, 896-901. [CrossRef]

185. Ždralević, M.; Brand, A.; Di Ianni, L.; Dettmer, K.; Reinders, J.; Singer, K.; Peter, K.; Schnell, A.; Bruss, C.; Decking, S.-M.; et al. Double genetic disruption of lactate dehydrogenases A and B is required to ablate the "Warburg effect" restricting tumor growth to oxidative metabolism. J. Biol. Chem. 2018, 293, 15947-15961. [CrossRef]

186. Boudreau, A.; Purkey, H.E.; Hitz, A.; Robarge, K.; Peterson, D.; Labadie, S.; Kwong, M.; Hong, R.; Gao, M.; Del Nagro, C.; et al. Metabolic plasticity underpins innate and acquired resistance to LDHA inhibition. Nat. Chem. Biol. 2016, 12, 779-786. [CrossRef]

187. Rai, G.; Brimacombe, K.R.; Mott, B.T.; Urban, D.J.; Hu, X.; Yang, S.-M.; Lee, T.D.; Cheff, D.M.; Kouznetsova, J.; Benavides, G.A.; et al. Discovery and optimization of potent, cell active pyrazole-based inhibitors of lactate dehydrogenase (LDH). J. Med. Chem. 2017, 60, 9184-9204. [CrossRef]

188. Fang, A.; Zhang, Q.; Fan, H.; Zhou, Y.; Yao, Y.; Zhang, Y.; Huang, X. Discovery of human lactate dehydrogenase A (LDHA) inhibitors as anticancer agents to inhibit the proliferation of MG-63 osteosarcoma cells. Med. Chem. Commun. 2017, 8, 1720-1726. [CrossRef]

189. Kim, E.-Y.; Chung, T.-W.; Han, C.W.; Park, S.Y.; Park, K.H.; Jang, S.B.; Ha, K.-T. A novel lactate dehydrogenase inhibitor, 1-(phenylseleno)-4-(trifluoromethyl) benzene, suppresses tumor growth through apoptotic cell death. Sci. Rep. 2019, 9, 1-12. [CrossRef] [PubMed]

190. Zhou, Y.; Tao, P.; Wang, M.; Xu, P.; Lu, W.; Lei, P.; You, Q. Development of novel human lactate dehydrogenase-A inhibitors: High-throughput screening, synthesis, and biological evaluations. Eur. J. Med. Chem. 2019, 177, 105-115. [CrossRef]

191. Jafary, F.; Ganjalikhany, M.R.; Moradi, A.; Hemati, M.; Jafari, S. Novel peptide inhibitors for lactate dehydrogenase A (LDHA): A survey to inhibit LDHA activity via disruption of protein-protein interaction. Sci. Rep. 2019, 9, 4686. [CrossRef] [PubMed]

192. Sonveaux, P.; Copetti, T.; De Saedeleer, C.J.; Végran, F.; Verrax, J.; Kennedy, K.M.; Moon, E.J.; Dhup, S.; Danhier, P.; Frérart, F.; et al. Targeting the lactate transporter MCT1 in endothelial cells inhibits lactate induced HIF-1 activation and tumor angiogenesis. PLoS ONE 2012, 7, e33418. [CrossRef]

193. Guan, X.; Rodriguez-Cruz, V.; Morris, M.E. Cellular Uptake of MCT1 Inhibitors AR-C155858 and AZD3965 and Their Effects on MCT-Mediated Transport of L-Lactate in Murine 4T1 Breast Tumor Cancer Cells. AAPS J. 2019, 21, 13. [CrossRef]

194. Doherty, J.R.; Yang, C.; Scott, K.E.N.; Cameron, M.D.; Fallahi, M.; Li, W.; Hall, M.A.; Amelio, A.L.; Mishra, J.K.; $\mathrm{Li}$, F.; et al. Blocking lactate export by inhibiting the Myc target MCT1 disables glycolysis and glutathione synthesis. Cancer Res. 2014, 74, 908-920. [CrossRef] 
195. Polański, R.; Hodgkinson, C.L.; Fusi, A.; Nonaka, D.; Priest, L.; Kelly, P.; Trapani, F.; Bishop, P.W.; White, A.; Critchlow, S.E.; et al. Activity of the monocarboxylate transporter 1 inhibitor AZD3965 in small cell lung cancer. Clin. Cancer Res. 2014, 20, 926-937. [CrossRef]

196. Benjamin, D.; Robay, D.; Hindupur, S.K.; Pohlmann, J.; Colombi, M.; El-Shemerly, M.Y.; Maira, S.-M.; Moroni, C.; Lane, H.A.; Hall, M.N. Dual inhibition of the lactate transporters MCT1 and MCT4 is synthetic lethal with metformin due to NAD+ depletion in cancer cells. Cell Rep. 2018, 25, 3047-3058. [CrossRef]

197. Ždralević, M.; Vučetić, M.; Daher, B.; Marchiq, I.; Parks, S.K.; Pouysségur, J. Disrupting the 'Warburg effect' re-routes cancer cells to OXPHOS offering a vulnerability point via 'ferroptosis'-induced cell death. Adv. Biol. Regul. 2018, 68, 55-63. [CrossRef]

198. Bola, B.M.; Chadwick, A.L.; Michopoulos, F.; Blount, K.G.; Telfer, B.A.; Williams, K.J.; Smith, P.D.; Critchlow, S.E.; Stratford, I.J. Inhibition of monocarboxylate transporter-1 (MCT1) by AZD3965 enhances radiosensitivity by reducing lactate transport. Mol. Cancer Ther. 2014, 13, 2805-2816. [CrossRef]

199. Sanità, P.; Capulli, M.; Teti, A.; Galatioto, G.P.; Vicentini, C.; Chiarugi, P.; Bologna, M.; Angelucci, A. Tumor-stroma metabolic relationship based on lactate shuttle can sustain prostate cancer progression. BMC Cancer. 2014, 14, 154. [CrossRef] [PubMed]

200. Cross, M.J.; Claesson-Welsh, L. FGF and VEGF function in angiogenesis: Signalling pathways, biological responses and therapeutic inhibition. Trends Pharmacol. Sci. 2001, 22, 201e207. [CrossRef]

201. Quanz, M.; Bender, E.; Kopitz, C.; Grünewald, S.; Schlicker, A.; Schwede, W.; Eheim, A.; Toschi, L.; Neuhaus, R.; Richter, C.; et al. Preclinical efficacy of the novel monocarboxylate transporter 1 inhibitor BAY-8002 and associated markers of resistance. Mol. Cancer Ther. 2018, 17, 2285-2296. [CrossRef]

202. Marchiq, I.; Le Floch, R.; Roux, D.; Simon, M.P.; Pouyssegur, J. Genetic disruption of lactate/Hp symporters (MCTs) and their subunit CD147/ BASIGIN sensitizes glycolytic tumor cells to phenformin. Cancer Res. 2015, 75, 171-180. [CrossRef]

203. Noble, R.A.; Bell, N.; Blair, H.; Sikka, A.; Thomas, H.; Phillips, N.; Nakjang, S.; Miwa, S.; Crossland, R.; Rand, V.; et al. Inhibition of monocarboxyate transporter 1 by AZD3965 as a novel therapeutic approach for diffuse large B-cell lymphoma and Burkitt lymphoma. Haematologica 2017, 102, 1247-1257. [CrossRef]

204. Curtis, N.J.; Mooney, L.; Hopcroft, L.; Michopoulos, F.; Whalley, N.; Zhong, H.; Murray, C.; Logie, A.; Revill, M.; Byth, K.F.; et al. Pre-clinical pharmacology of AZD3965, a selective inhibitor of MCT1: DLBCL, NHL and Burkitt's lymphoma anti-tumor activity. Oncotarget 2017, 8, 69219-69236. [CrossRef]

205. Follman, K.E.; Morris, M.E. Treatment of $\gamma$-hydroxybutyric acid (GHB) and $\gamma$-butyrolactone (GBL) overdose with two potent monocarboxylate transporter 1 (MCT1) inhibitors, AZD3965 and AR-C155858. J. Pharmacol. Exp. Ther. 2019, 370, 84-91. [CrossRef]

206. Hao, J.; Chen, H.; Madigan, M.C.; Cozzi, P.J.; Beretov, J.; Xiao, W.; Delprado, W.J.; Russell, P.J.; Li, Y. Co-expression of CD147 (EMMPRIN), CD44v3-10, MDR1 and monocarboxylate transporters is associated with prostate cancer drug resistance and progression. Br. J. Cancer. 2010, 103, 1008-1018. [CrossRef]

207. Chiche, J.; Le Fur, Y.; Vilmen, C.; Frassineti, F.; Daniel, L.; Halestrap, A.P.; Cozzone, P.J.; Pouysségur, J.; Lutz, N.W. In vivo $\mathrm{pH}$ in metabolic-defective Ras-transformed fibroblast tumors: Key role of the monocarboxylate transporter, MCT4, for inducing an alkaline intracellular pH. Int. J Cancer. 2012, 130, 1511-1520. [CrossRef]

208. Sasaki, S.; Futagi, Y.; Ideno, M.; Kobayashi, M.; Narumi, K.; Furugen, A.; Iseki, K. Effect of diclofenac on SLC16A3/MCT4 by the Caco-2 cell line. Drug Metab. Pharmacokinet. 2016, 31, 218-223. [CrossRef]

209. Futagi, Y.; Kobayashi, M.; Narumi, K.; Furugen, A.; Iseki, K. Identification of a selective inhibitor of human monocarboxylate transporter 4. Biochem. Biophys. Res. Commun. 2018, 495, 427-432. [CrossRef]

210. Marchiq, I.; Pouyssegur, J. Hypoxia, cancer metabolism and the therapeutic benefit of targeting lactate/ $\mathrm{H}(+)$ symporters. J. Mol. Med. 2016, 94, 155-171. [CrossRef]

211. Nancolas, B.; Guo, L.; Zhou, R.; Nath, K.; Nelson, D.S.; Leeper, D.B.; Blair, I.A.; Glickson, J.D.; Halestrap, A.P. The anti-tumour agent lonidamine is a potent inhibitor of the mitochondrial pyruvate carrier and plasma membrane monocarboxylate transporters. Biochem. J. 2016, 473, 929-936. [CrossRef] [PubMed]

212. Wang, C.; Wen, Z.; Xie, J.; Zhao, Y.; Zhao, L.; Zhang, S.; Liu, Y.; Xue, Y.; Shi, M. MACC1 mediates chemotherapy sensitivity of 5-FU and cisplatin via regulating MCT1 expression in gastric cancer. Biochem. Biophys. Res. Commun. 2017, 485, 665-671. [CrossRef] 
213. Wilson, M.C.; Meredith, D.; Fox, J.E.M.; Manoharan, C.; Davies, A.J.; Halestrap, A.P. Basigin (CD147) is the target for organomercurial inhibition of monocarboxylate transporter isoforms 1 and 4: The ancillary protein for the insensitive MCT2 is EMBIGIN (gp70). J. Biol. Chem. 2005, 280, 27213-27221. [CrossRef]

214. Fu, Z.-G.; Wang, L.; Cui, H.-Y.; Peng, J.-L.; Wang, S.-J.; Geng, J.-J.; Liu, J.-D.; Feng, F.; Song, F.; Li, L.; et al. A novel small-molecule compound targeting CD147 inhibits the motility and invasion of hepatocellular carcinoma cells. Oncotarget 2016, 7, 9429-9447. [CrossRef]

215. Zhang, Z.; Zhang, Y.; Sun, Q.; Feng, F.; Hube, M.; Mi, L.; Chen, Z. Preclinical pharmacokinetics, tolerability, and pharmacodynamics of metuzumab, a novel CD147 human mouse chimeric and glycol engineered antibody. Mol. Cancer Ther. 2015, 14, 162-173. [CrossRef] [PubMed]

Publisher's Note: MDPI stays neutral with regard to jurisdictional claims in published maps and institutional affiliations.

(C) 2020 by the authors. Licensee MDPI, Basel, Switzerland. This article is an open access article distributed under the terms and conditions of the Creative Commons Attribution (CC BY) license (http://creativecommons.org/licenses/by/4.0/). 